\title{
Life-Cycle Assessment of a Regulatory Compliant U.S. Municipal Solid Waste Landfill
}

Yixuan Wang, "James W. Levis, and Morton A. Barlaz

North Carolina State University, Department of Civil, Construction, and Environmental Engineering, Campus Box 7908, Raleigh, NC 27695-7908

*Corresponding author. Email: ywang151@ncsu.edu

Supporting Information

Number of pages: 44

Number of tables: 15

Number of figures: 29 


\section{TABLE OF CONTENTS}

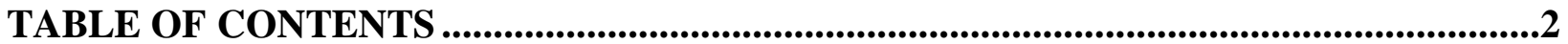

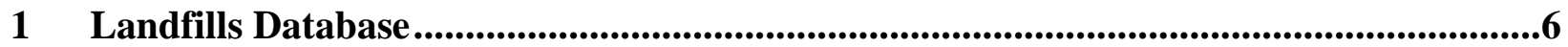

2 Life Cycle Inventory of Landfill Modules ..........................................................8

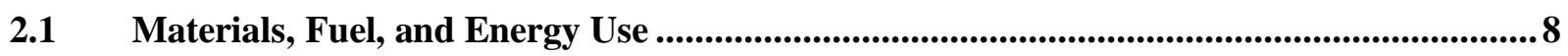

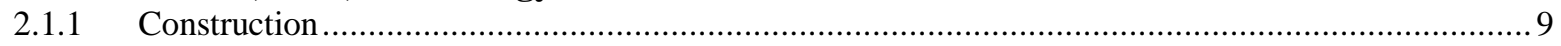

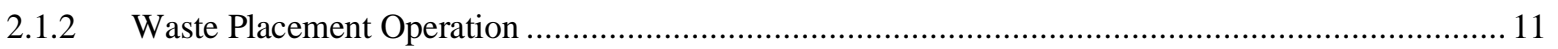

2.1.3 Final Cover Placement and Closure

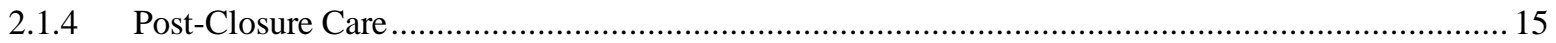

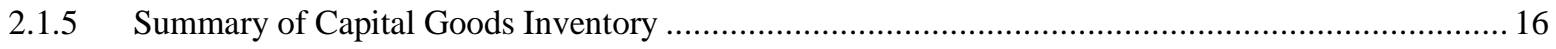

2.2 Landfill Gas Generation, Collection, and Control ...........................................................19

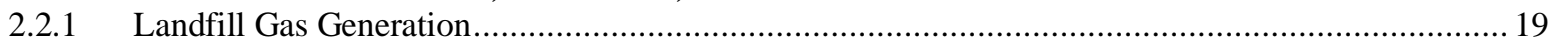

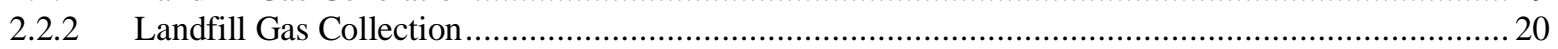

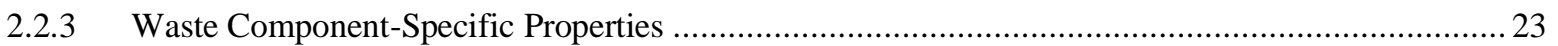

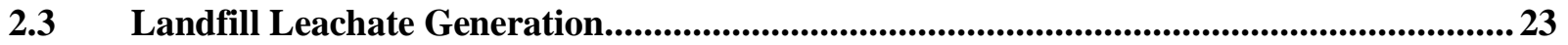

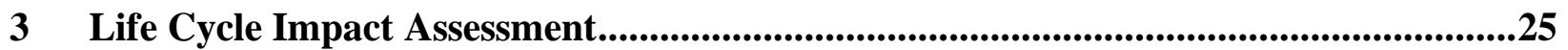

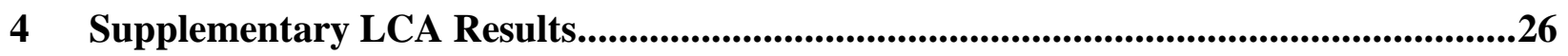

4.1 Life-Cycle Impact Results and Major Flow Contributors by Impact Category ...............26

4.2 Landfill Methane Profile .............................................................................................34

5 Monte Carlo Analysis Inputs and Distributions........................................................39

6 Effect of NMOC Threshold on Gas Collection Efficiency under Uncertainty ..............42

$7 \quad$ Reference ........................................................................................................................................

\section{List of Tables}

Table S1. Statistical comparison between LMOP and GHGRP database based on waste

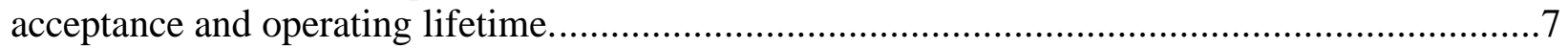

Table S2. Landfill design profile and waste characteristics ......................................... 8

Table S3. Density of liner and cover construction materials (Internet source) .........................10 Table S4. Bottom liner cross section layer thicknesses and other inputs for the construction of the leachate collection and control system.................................................................... 10

Table S5. Vertical gas well installation parameters ......................................................11

Table S6. Parameters used to estimate the electricity, fuel and heavy equipment use for landfill operations.

Table S7. Final cover layer thicknesses and other parameters used to model the piping and collection well installation, fuel and heavy equipment used in heavy equipment, and transportation of fuel and materials to the site during the final cover placement and landfill closure.

Table S8. Timeframe, fuel use, and percentage of cover replacement during the post-closure care period. 
Table S9. Summary of intermediate calculations (e.g., land surface area and volume of waste buried) for materials, fuel, and electricity used for the construction, operation, closure, and postclosure care phases of the landfill life cycle.

Table S10. Final life-cycle inventory of materials, electricity, fuel uses, and transportation based on $1 \mathrm{Mg}$ of waste buried in a 'large' landfill that has a mean annual waste acceptance of 233,091 $\mathrm{Mg} / \mathrm{yr}$ and a 80 -yr operating years.

Table S11. Landfill Gas Collection Inputs and Landfill Gas Combustion System Parameters Used in the Flare and Energy Recovery Scenarios.

Table S12. Methane Production Potential $\left(\mathrm{L}_{0}\right)$ and Field Decay Rate for Eight MSW

Components ${ }^{a}$....

Table S13. Landfill Leachate Generation Rate as a Percentage of Precipitation Varying with Time and Cover Type ${ }^{a}$

Table S14. Normalization factors for ten impact categories based on U.S. 2008 according to TRACI v2. $1^{11}$

Table S15. Default values, ranges, and distribution of uncertain inputs for Monte Carlo analysis.

\section{List of Figures}

Figure S1. Evaluation of the distribution from the 10,000 random samples of (a) waste acceptance and (b) operating years based on the LMOP landfill database ............................. Figure S2. Landfill construction system boundary .................................................9 Figure S3. Leachate collection pipes spacing along the landfill prism...................................11 Figure S4. Waste placement operation system boundary. On-site soil is the default for daily cover and no emissions from daily cover transport were included. Alternatives for daily cover materials could be off-site soil, HDPE tarps, or revenue-generating cover (e.g., compost, yard

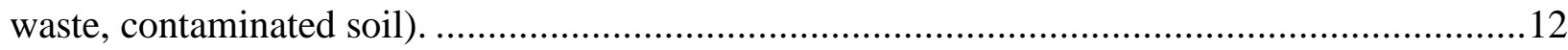

Figure S5. Landfill closure system boundary ................................................................ 14

Figure S6. Post-closure care system boundary ......................................................... 16

Figure S7. Conceptual diagram for time-varying collection efficiency that depends on the year waste is buried in the cell and waste age.

Figure S8. Temporally averaged annual gas collection efficiency for the flare scenario across four gas collection schedules, four decay rate constants, and NMOC thresholds.....................22 Figure S9. Temporally averaged annual gas collection efficiency for the energy recovery scenario across four gas collection schedules and four decay rate constants. Figure S10. Temporally averaged percentage of precipitation that becomes leachate based on the assumptions in Table S11.

Figure S11. (a) Critical flow contributors that cumulatively contribute $90 \%$ of the acidification (ACID) impact, (b) contribution of critical flows from capital goods and landfill treatment, and (c) contribution of composite materials consumed.

Figure S12. (a) Critical flow contributors that cumulatively contribute $90 \%$ of the ecotoxicity (ETOX) impact, (b) contribution of critical flows from capital goods and landfill treatment, and

(c) contribution of composite materials consumed.

Figure S13. (a) Critical flow contributors that cumulatively contribute $90 \%$ of the eutrophication (ETP) impact, (b) contribution of critical flows from capital goods and landfill treatment, and (c) contribution of composite materials consumed. 
Figure S14. (a) Critical flow contributors that cumulatively contribute $90 \%$ of the fossil fuel depletion (FFD) impact, (b) contribution of critical flows from capital goods and landfill treatment, and (c) contribution of composite materials consumed.....

Figure S15. (a) Critical flow contributors that cumulatively contribute $90 \%$ of the global warming (GW) impact, (b) contribution of critical flows from capital goods and landfill treatment, and (c) contribution of composite materials consumed.

Figure S16. (a) Critical flow contributors that cumulatively contribute $90 \%$ of the human health cancer (HHc) impact, (b) contribution of critical flows from capital goods and landfill treatment, and (c) contribution of composite materials consumed.

Figure S17. (a) Critical flow contributors that cumulatively contribute $90 \%$ of the human health non-cancer (HHNc) impact, (b) contribution of critical flows from capital goods and landfill treatment, and (c) contribution of composite materials consumed.

Figure S18. (a) Critical flow contributors that cumulatively contribute $90 \%$ of the ozone depletion (OD) impact, (b) contribution of critical flows from capital goods and landfill treatment, and (c) contribution of composite materials consumed. The data used to generate this result is the composition of LFG as presented in the U.S. EPA AP-42 database. ${ }^{12}$ The trace organic constituents in LFG in this database are based on LFG composition data from the 1990s and the CFCs likely result from refrigerants in appliances. CFC concentrations have likely decreased over time.

Figure S19. (a) Critical flow contributors that cumulatively contribute $90 \%$ of the respiratory effect (RE), (b) contribution of critical flows from capital goods and landfill treatment, and (c) contribution of composite materials consumed.

Figure S20. (a) Critical flow contributors that cumulatively contribute $90 \%$ of the smog (SMOG), (b) contribution of critical flows from capital goods and landfill treatment, and (c) contribution of composite materials consumed.

Figure S21. (a) Normalized impacts as person equivalent (PE) and (b) contributions of capital goods and landfill gas and leachate emissions for the electricity recovery scenarios with the EPA Typical collection across two NMOCs threshold for gas regulation and ten impact categories...32 Figure S22. Contributions of capital goods (electricity, fuel, material, transportation) and landfill gas and leachate emissions across ten impact categories based on the flare scenario and EPA Typical collection schedule

Figure S23. Landfill methane inventory that is collected and flared, oxidized, and emitted based on the flare scenarios and EPA Typical collection across five landfill types (i.e., four decay rate constants and the representative landfill that is a composite of four decay rates) and two flare turnoff NMOCs thresholds.

Figure S24. Landfill methane inventory that is collected and flared, oxidized, and emitted based on the electricity recovery scenarios and EPA Typical collection across five landfill types (i.e., four decay rate constants and the representative landfill that is a composite of four decay rates) and two flare turnoff NMOCs thresholds.

Figure S25. Percentage of emissions that are released by 20 and $100 \mathrm{yr}$. Results are based on the energy recovery scenario and EPA Typical collection across five landfill types (i.e., four decay rate constants and the representative landfill that is a weighted average of four decay rates)......36 Figure S26. The fraction of generated methane that is combusted to produce electricity, flared, oxidized, and emitted across two gas treatment and four gas collection scenarios by decay rate, based on the (a) flare and (b) electricity recovery scenarios. 
Figure S27. Effective collection efficiency of mixed MSW, corrugated cardboard, and vegetable waste under the flare scenarios with two NMOC thresholds and four decay rates across the range

of U.S. landfill sizes.

Figure S28. Percentage of $\mathrm{CH}_{4}$ generated by 20, 50, and $100 \mathrm{yr}$ across four decay rate constants

Figure S29. Boxplot showing the uncertainties associated with the increase in collection efficiency due to lowering the NMOC threshold from 50 to $34 \mathrm{Mg} / \mathrm{yr}$ across four decay rates. 42 


\section{LANDFILLS DATABASE}

We developed a lognormal statistical distributions for landfill size and operating lifetime based on the U.S. EPA's Landfill Methane Outreach Program (LMOP) database (Table 1) that contains key information about 2,629 MSW landfills and landfill gas (LFG) energy projects in the U.S. ${ }^{1}$ However, not all landfills updated data each year or reported complete data. For example, some landfills miss the reporting of (viable) open/closure years so we cannot use it to estimate the potential operating life. Also, to provide practical recommendations for the potential candidates for energy recovery projects, we only considered the landfills that are closed after 2015. To obtain the useful information of size and operating life of LMOP landfills, we filtered the original 2,629 landfills into the remaining 1,108 landfills based on the following four principles: (1) removing 27 "unknown" landfills, (2) removing landfills that do not have sufficient data to determine the open/closure years or the year waste in place, (3) only keeping the open landfills and landfills closed within 5 years (after year 2015), and (4) removing duplicates (i.e., multiple energy project status records for unique landfill ID and only keep the latest record).

Table 1 shows that the mean waste acceptance of a U.S. landfill is 233,091 Mg MSW yr-1 and the mean operating life is $80 \mathrm{yr}$. Given that $1 \mathrm{Mg}$ of MSW is more likely to be disposed in a large landfill than in a small landfill, a lognormal distribution was developed by assigning a larger weight to larger landfills. The distribution of values sampled 10,000 times converged well with the assumed lognormal distribution (Figure S1).

The U.S. EPA's Greenhouse Gas Reporting Program (GHGRP) is another commonly used dataset for MSW landfills. ${ }^{2}$ While both LMOP and GHGRP database do not include data for every MSW landfill in the U.S., GHGRP only includes landfills that are compliant with the GHG reporting rule, those with $\mathrm{CH}_{4}$ emissions equivalent to $>25,000$ tonnes $\mathrm{CO}_{2}$ e. Also, only 978 landfills reported available and nonzero data on both annual waste acceptance and operating years, where only 955 landfills are closed after 2015. The GHGRP dataset contains fewer operating landfills with useful information used to estimate landfill size, operating lifetime, and design (Table S1). In contrast, the LMOP dataset includes more smaller operating landfills from which $\mathrm{CH}_{4}$ emissions are $\leq 25,000$ tonnes $\mathrm{CO}_{2} \mathrm{e}$. Therefore, we chose LMOP database over GHGRP to provide recommendations for a larger range of U.S. landfills. 
Table S1. Statistical comparison between LMOP and GHGRP database based on waste acceptance and operating lifetime.

\begin{tabular}{lllllll}
\hline \multirow{2}{*}{ Statistics } & \multicolumn{2}{c}{ Annual Waste Acceptance (Mg/yr) } & \multicolumn{2}{c}{ Operating Years (yr) } \\
\cline { 2 - 7 } & GHGRP & LMOP & $\begin{array}{l}\text { \% Diff. of GHGRP } \\
\text { from LMOP }\end{array}$ & GHGRP & LMOP & $\begin{array}{l}\text { \% Diff. of GHGRP } \\
\text { from LMOP }\end{array}$ \\
\hline $1^{\text {st }}$ quartile & 82,557 & 67,791 & 22 & 51 & 16 & 219 \\
Median & 172,157 & 144,148 & 19 & 67 & 65 & 3 \\
Mean & 288,984 & 233,091 & 24 & 88 & 80 & 10 \\
$3^{\text {rd }}$ quartile & 349,165 & 265,081 & 32 & 91 & 89 & 2 \\
\hline
\end{tabular}

(a) Evaluation of the distribution of waste acceptance

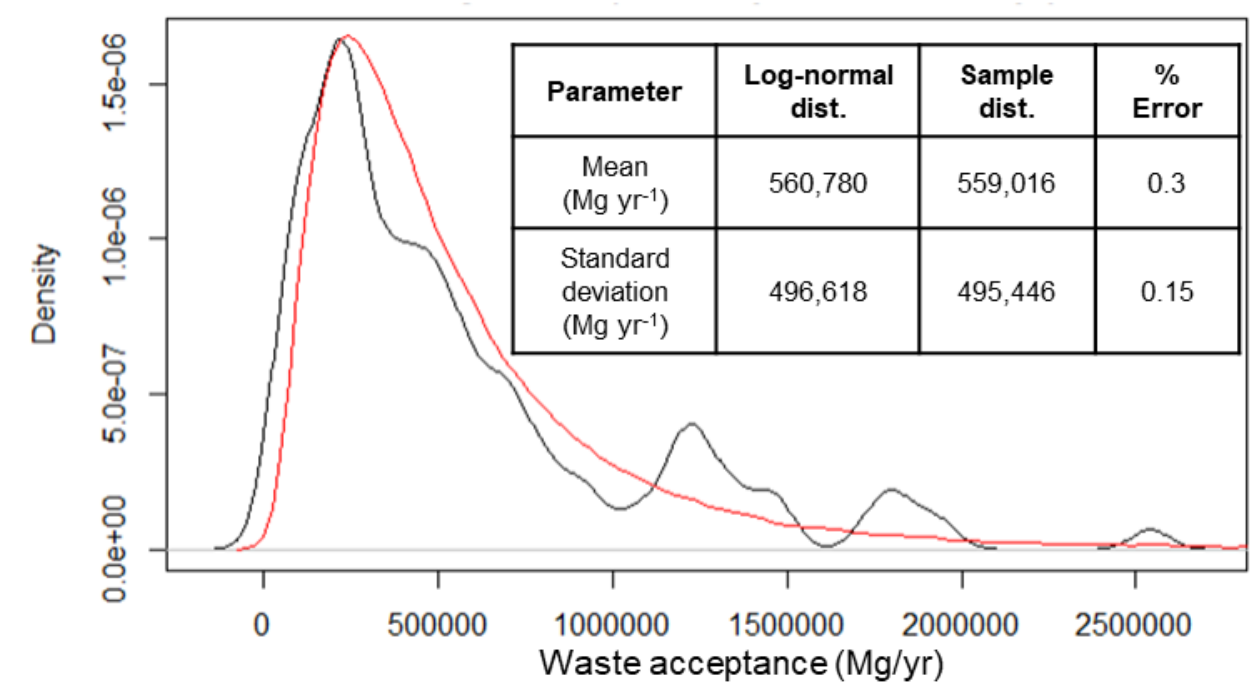

(b) Evaluation of the distribution of landfill operating life

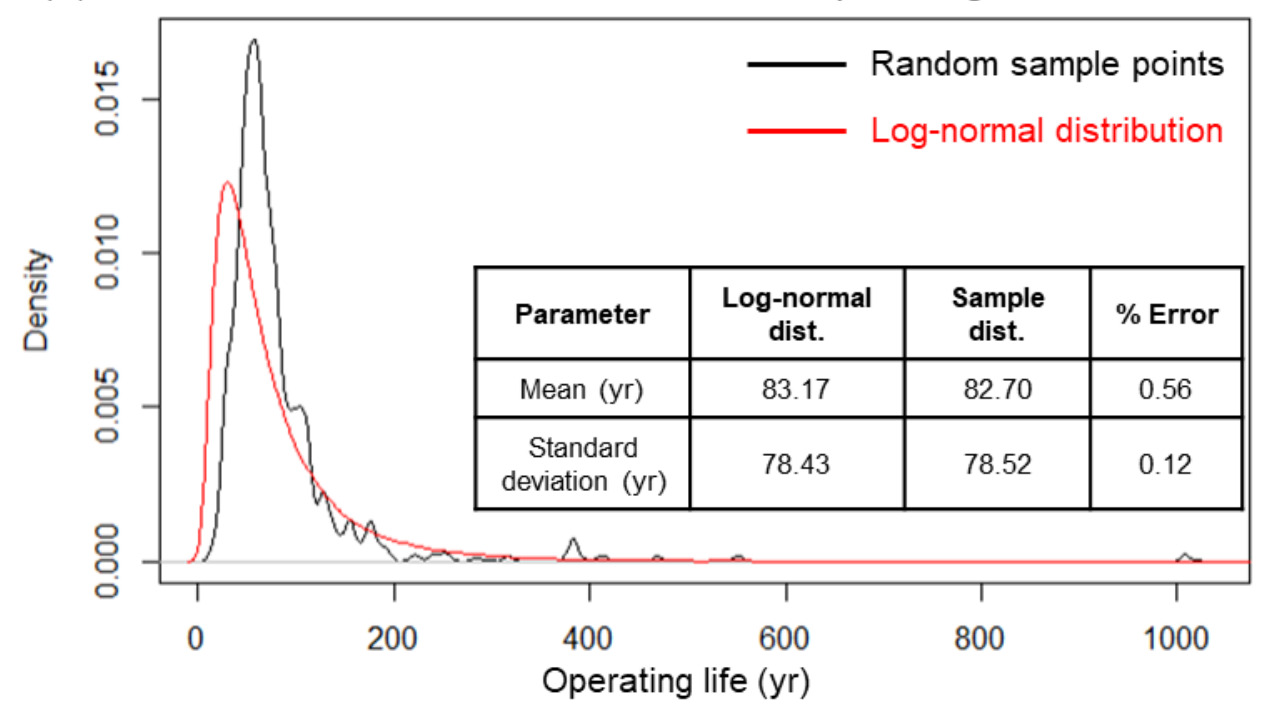

Figure S1. Evaluation of the distribution from the 100,000 random samples of (a) waste acceptance and (b) operating years based on the LMOP landfill database. The mean and standard deviation of the sampled distribution converged well with the assumed log-normal distribution. 


\section{LIFE CYCLE INVENTORY OF LANDFILL MODULES}

A landfill life-cycle model was developed to estimate the emissions attributable to capital goods and resources consumed during landfill construction, operation, closure, and post-closure, as well as emissions attributable to LFG and leachate. The functional unit for the model is the behavior of $1 \mathrm{Mg}\left(10^{3} \mathrm{~kg}\right)$ of wet MSW discarded in a landfill. The system boundary includes emissions from the extraction and production of materials used for construction, transportation of materials and fuels, and net electricity production.

A series of physical, chemical, and biological reactions are initiated when waste is buried in a landfill. These reactions result in LFG generation as well as the release of contaminants to leachate. The system includes gas generation, collection, flaring, beneficial LFG reuse for energy and associated offsets, and $\mathrm{CH} 4$ oxidation in the cover soil. Leachate emissions are estimated from the volume generated and the release of contaminants (e.g., $\mathrm{BOD}, \mathrm{COD}, \mathrm{NH}_{3}-\mathrm{N}$ ) after treatment, and the resulting biosolids management.

Table S2. Landfill design profile and waste characteristics

\begin{tabular}{|c|c|c|c|}
\hline Parameter & Unit & Value & Comment \\
\hline Waste acceptance per year & $\mathrm{Mg} / \mathrm{yr}$ & 233,091 & $\begin{array}{l}\text { Mean annual waste acceptance rate based on } \\
\text { LMOP landfill database }\end{array}$ \\
\hline Annual operating days & days/yr & 260 & \\
\hline Operating years (useful life) & $\mathrm{yr}$ & 80 & $\begin{array}{l}\text { Mean operating life based on LMOP landfill } \\
\text { database }\end{array}$ \\
\hline Waste density & $\mathrm{kg} / \mathrm{m}^{3}$ & 1068 & $\begin{array}{l}\text { Small landfills receiving <200,000 Mg/yr: } 1500 \\
\mathrm{lb} / \mathrm{yd}^{3}\left(890 \mathrm{~kg} / \mathrm{m}^{3}\right) ; \text { large landfills receiving } \\
\geq 200,000 \mathrm{Mg} / \mathrm{yr}: 1800 \mathrm{lb} / \mathrm{yds}\left(1068 \mathrm{~kg} / \mathrm{m}^{3}\right)\end{array}$ \\
\hline $\begin{array}{l}\text { Height of top of landfill } \\
\text { above grade }\end{array}$ & $\mathrm{m}$ & 60.96 & $\begin{array}{l}\text { Small landfill: } 100 \mathrm{ft} \text {; large landfill: } 200 \mathrm{ft} \text {. See } \\
\text { Figure } 1 .\end{array}$ \\
\hline Depth of excavation & $\mathrm{m}$ & 7.62 & $\begin{array}{l}\text { Small landfill: } 20 \mathrm{ft} \text {; large landfill: } 25 \mathrm{ft} \text {. See } \\
\text { Figure } 1 .\end{array}$ \\
\hline $\begin{array}{l}\text { Ratio of length to width of } \\
\text { landfill }\end{array}$ & unitless & 1 & \\
\hline $\begin{array}{l}\text { Slope (vertical to } \\
\text { horizontal) }\end{array}$ & unitless & 0.33 & Rise over run: 1 to 3 . See Figure 1. \\
\hline
\end{tabular}

\subsection{Materials, Fuel, and Energy Use}

Heavy equipment is required in all phases from construction, operation, closure, through after-closure care. Emissions associated with these heavy equipment consumptions were estimated based on the materialization of an "Industrial machine, heavy, unspecified" (i.e., assuming a rock crusher) from the 
Ecoinvent v 3.6, ${ }^{3}$ which is consistent with the background profile used to represent heavy equipment used to mine other materials (e.g., clay and sand pit operation). This heavy equipment is built with metal materials, of which low-alloyed and hot-alloyed steel constitutes $\sim 91 \%$ and other metals include cast iron, aluminum, and bronze.

\subsubsection{Construction}

Landfill construction involves the use of materials and dedicated heavy equipment whose production contributes to the landfill life cycle inventory. Fuel combusted in construction equipment (e.g., wheeled tractor-scraper) and heavy-duty trucks transporting fuel and materials are also included in the life cycle inventory associated with liner construction. Figure S2 illustrates the system boundary for the construction module of the landfill life cycle. Table S3 and Table S3

Table S4 present the input parameters describing the liner system design. These inputs are used to calculate the quantities of materials, fuel, and equipment during landfill construction.

Gas collection wells are installed over time and prior to final cover placement. Table S5 shows the parameters for vertical gas well installation.

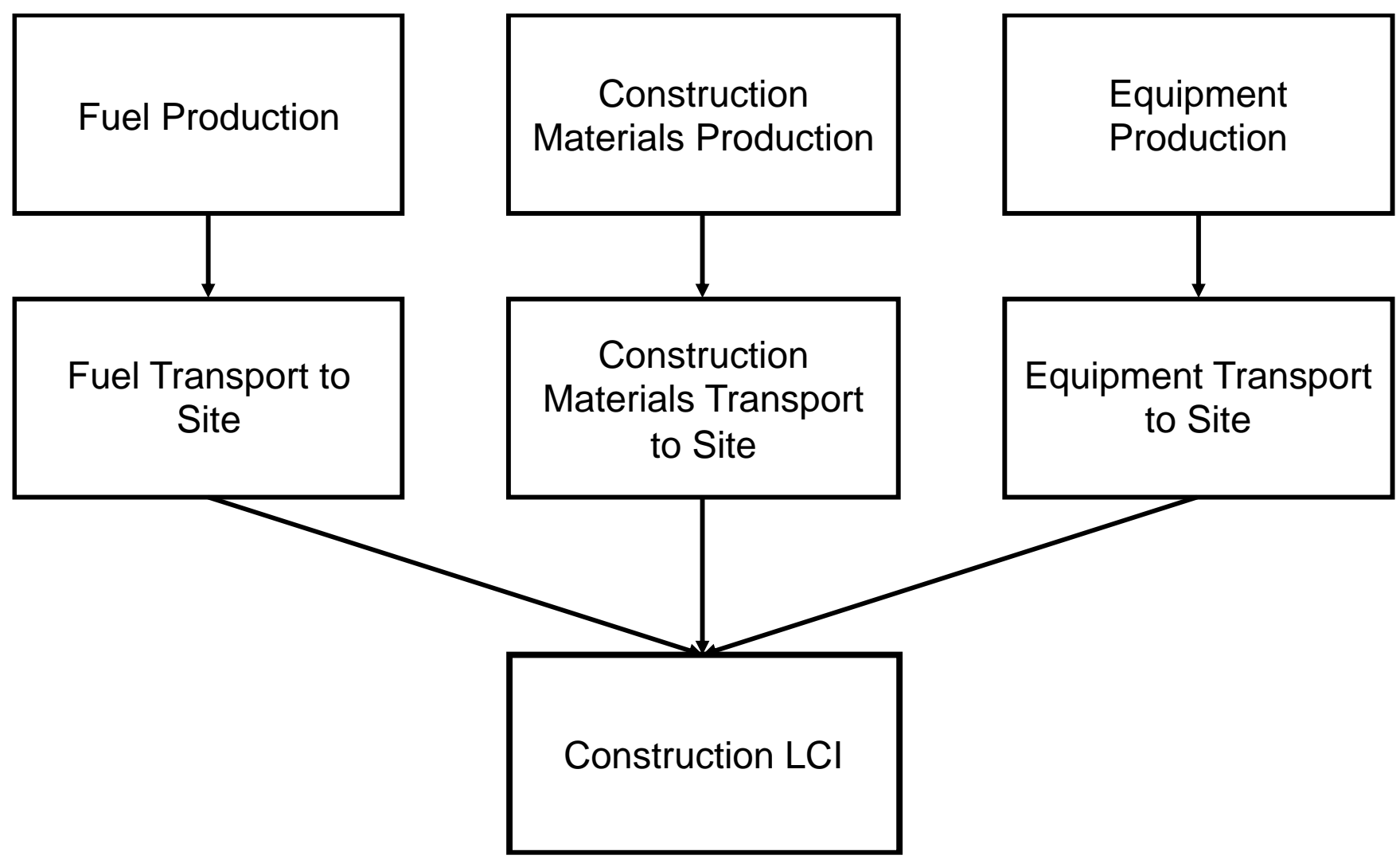

Figure S2. Landfill construction system boundary 
Table S3. Density of liner and cover construction materials (Internet source)

\begin{tabular}{lcl}
\hline Density of capital goods & Value & Unit \\
\hline Density of soil & 1842 & $\mathrm{~kg} / \mathrm{m}^{3}$ \\
Density of asphalt & 1038 & $\mathrm{~kg} / \mathrm{m}^{3}$ \\
Density of sand & 1562 & $\mathrm{~kg} / \mathrm{m}^{3}$ \\
Density of clay & 1842 & $\mathrm{~kg} / \mathrm{m}^{3}$ \\
Density of gravel & 1520 & $\mathrm{~kg} / \mathrm{m}^{3}$ \\
Density of concrete & 2374 & $\mathrm{~kg} / \mathrm{m}^{3}$ \\
Density of HDPE & 955 & $\mathrm{~kg} / \mathrm{m}^{3}$ \\
Density of PVC & 1350 & $\mathrm{~kg} / \mathrm{m}^{3}$ \\
Density of geotextile & 94.1 & $\mathrm{~kg} / \mathrm{m}^{3}$ \\
Density of HDPE pipe & 4.7 & $\mathrm{~kg} / \mathrm{m}$ \\
Density of PVC pipe & 3 & $\mathrm{~kg} / \mathrm{m}$ \\
Density of diesel & 0.84 & $\mathrm{~kg} / \mathrm{L}$ \\
\hline
\end{tabular}

Table S4. Bottom liner cross section layer thicknesses and other inputs for the construction of the leachate collection and control system.

\begin{tabular}{|c|c|c|c|}
\hline Parameter & Value & Unit & Comment \\
\hline Thickness of sand & 0.61 & $\mathrm{~m}$ & 2 feet \\
\hline Thickness of HDPE liner & 0.0015 & $\mathrm{~m}$ & 60 mil \\
\hline Thickness of clay & 0.61 & $\mathrm{~m}$ & 2 feet \\
\hline $\begin{array}{l}\text { Leachate collection pipe on } \\
\text { the landfill bottom }\end{array}$ & 30.48 & $\mathrm{~m}$ & 100 feet, Figure S3. \\
\hline $\begin{array}{l}\text { Fraction of HDPE used for } \\
\text { piping (PVC is the alternate) }\end{array}$ & 1 & unitless & $\begin{array}{l}1 \text { means all HDPE pipes while } 0 \text { means } \\
\text { all PVC pipes in the leachate collection } \\
\text { and control system }\end{array}$ \\
\hline Heavy equipment & 0.016 & $\mathrm{~kg} / \mathrm{Mg}$ & $\begin{array}{l}\text { Wheeled tractor-scraper is the } \\
\text { predominant equipment }{ }^{a}\end{array}$ \\
\hline Number of leachate sumps & 5 & sumps & $\begin{array}{l}\text { Reinforced concrete was used for sumps } \\
\text { that collect leachate }\end{array}$ \\
\hline Thickness of sump wall & 0.076 & $\mathrm{~m}$ & \\
\hline Diameter of sump & 0.62 & $\mathrm{~m}$ & \\
\hline Depth of sump excavation & 7.62 & $\mathrm{~m}$ & \\
\hline Asphalt used for roadways & 0.085 & $\mathrm{~kg} / \mathrm{Mg}$ & Asphalt \\
\hline $\begin{array}{l}\text { Diesel consumed by } \\
\text { equipment }\end{array}$ & 0.22 & $\mathrm{~L} / \mathrm{Mg}$ & Average estimates based on field data ${ }^{b, c}$ \\
\hline Payload medium duty truck & 24 & $\mathrm{Mg}$ & \\
\hline Payload heavy duty truck & 30 & $\mathrm{Mg}$ & \\
\hline Clay haul distance & 8 & $\mathrm{~km}$ & Field data ${ }^{c}$ \\
\hline Sand haul distance & 32 & $\mathrm{~km}$ & Field data ${ }^{c}$ \\
\hline $\begin{array}{l}\text { Heavy equipment haul } \\
\text { distance }\end{array}$ & 402 & $\mathrm{~km}$ & Field data ${ }^{c}$ \\
\hline Concrete haul distance & 80 & $\mathrm{~km}$ & Field data ${ }^{c}$ \\
\hline
\end{tabular}




\begin{tabular}{lrll}
\hline Parameter & Value & Unit & Comment \\
\hline Asphalt haul distance & 80 & $\mathrm{~km}$ & Field data $^{c}$ \\
HDPE (liners and pipes) haul & 402 & $\mathrm{~km}$ & Field data $^{c}$ \\
distance & & & \\
PVC pipes haul distance & 402 & $\mathrm{~km}$ & Field data $^{c}$ \\
Fuel haul distance & 80 & $\mathrm{~km}$ & Field data $^{c}$ \\
\hline
\end{tabular}

${ }^{a}$ The average heavy equipment use per $\mathrm{Mg}$ of waste was calculated based on the average number of hours per $\mathrm{Mg}$ of waste, lifetime of the predominant equipment, and the equipment weight. Heavy equipment use $(\mathrm{kg} / \mathrm{Mg})=[$ hours $/ \mathrm{Mg}$ waste $] /$ [Lifetime hours/equipment ${ }^{*}[\mathrm{~kg} /$ equipment $]$

${ }^{b}$ The fuel use value in the table is an input estimate describing the average fuel use per $\mathrm{Mg}$ of waste corresponding to the equipment use. The hours and types of equipment are based on field data. Some sites reported hours of heavy equipment use, which was multiplied by the fuel economy (L fuel/hr) of the equipment and then divided by the amount of waste. Other sites directly reported the fuel consumption which were divided by the amount of waste received.

${ }^{c}$ Based on the site questionnaire from the Ecobalance report. ${ }^{4,5}$

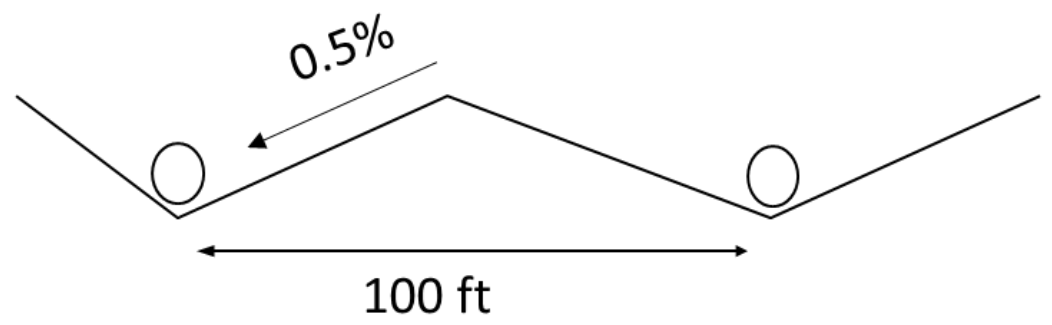

Figure S3. Leachate collection pipes spacing along the landfill prism

Table S5. Vertical gas well installation parameters

\begin{tabular}{|c|c|c|c|}
\hline Parameter & Value & Unit & Comment \\
\hline $\begin{array}{l}\text { Fraction of HDPE used for piping } \\
\text { (PVC is the alternate) }\end{array}$ & 1 & unitless & $\begin{array}{l}1 \text { represents all HDPE pipes while } 0 \\
\text { represents all PVC pipes in the gas } \\
\text { collection and control system. }\end{array}$ \\
\hline Length of vertical gas well & 58 & $\mathrm{~m}$ & $\begin{array}{l}\text { Assuming } 85 \% \text { of the landfill height. } \\
\text { For small landfills, } 0.85 * 120 \mathrm{ft}=102 \\
\mathrm{ft}[31 \mathrm{~m}] \text {; for large landfills, } 0.85 * \\
225 \mathrm{ft}=191 \mathrm{ft}[58 \mathrm{~m}] .\end{array}$ \\
\hline Density of gas collection well & 2.47E-04 & well $/ \mathrm{m}^{2}$ & 1 well/acre \\
\hline
\end{tabular}

\subsubsection{Waste Placement Operation}

Landfill operation involves the need for daily cover and dedicated heavy equipment (e.g., refuse compactor) to spread, compact and cover waste. Both equipment construction and soil cover excavation contribute to the landfill life cycle inventory. Figure S4 illustrates the system boundary for the operations 
module of the landfill life cycle. Table S6 presents the input parameters used to estimate the quantities of materials, electricity, fuel, and equipment required during landfill operation.

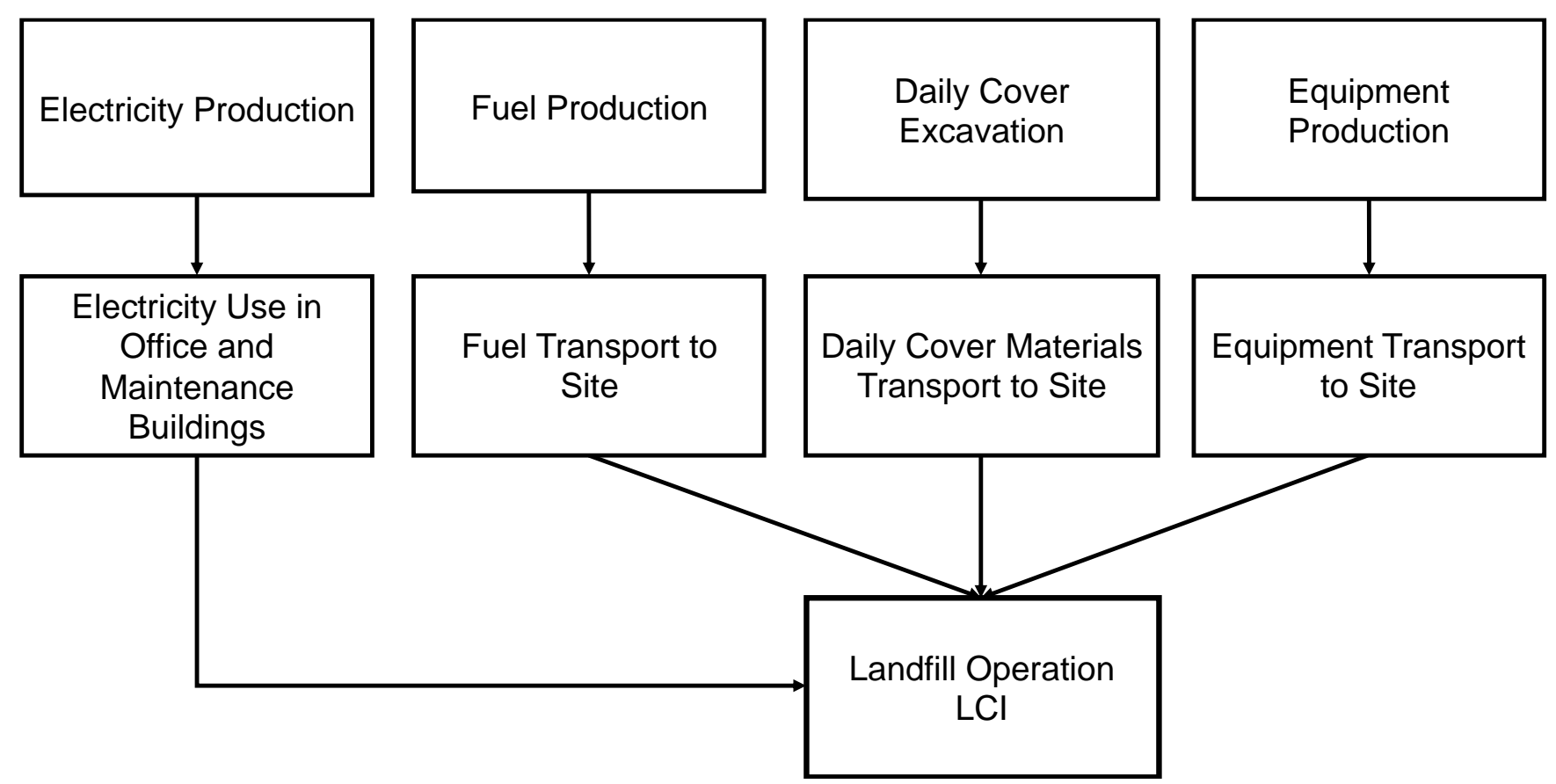

Figure S4. Waste placement operation system boundary. On-site soil is the default for daily cover and no emissions from daily cover transport were included. Alternatives for daily cover materials could be off-site soil, HDPE tarps, or revenue-generating cover (e.g., compost, yard waste, contaminated soil). 
Table S6. Parameters used to estimate the electricity, fuel and heavy equipment use for landfill operations.

\begin{tabular}{|c|c|c|c|}
\hline Parameter & Value & Unit & Comment \\
\hline Office area & 56 & $\mathrm{~m}^{2}$ & $\begin{array}{l}\text { Assuming a building area of } 50 \mathrm{ft} * 12 \mathrm{ft} \\
\text { for personnel office trailer }\end{array}$ \\
\hline Maintenance area & 372 & $\mathrm{~m}^{2}$ & $\begin{array}{l}\text { Assuming a building area of } 4,000 \mathrm{ft}^{2} \\
\text { for maintenance and equipment storage }\end{array}$ \\
\hline Office area electricity use & 256 & $\mathrm{kWh} / \mathrm{m}^{2}-\mathrm{yr}$ & \\
\hline $\begin{array}{l}\text { Equipment storage and } \\
\text { maintenance electricity use }\end{array}$ & 82 & $\mathrm{kWh} / \mathrm{m}^{2}-\mathrm{yr}$ & \\
\hline $\begin{array}{l}\text { Office and maintenance building } \\
\text { electricity }\end{array}$ & 0.081 & $\mathrm{kWh} / \mathrm{Mg}$ & $\begin{array}{l}\text { Calculated based on the office area and } \\
\text { electricity use per area per year. }\end{array}$ \\
\hline Daily cover or not? & TRUE & Logical & $\begin{array}{l}\text { Assuming daily and intermediate cover } \\
\text { was excavated on-site by default }\end{array}$ \\
\hline $\begin{array}{l}\text { Percentage of total landfill } \\
\text { occupied by daily and intermediate } \\
\text { cover }\end{array}$ & $\%$ & 10 & \\
\hline $\begin{array}{l}\text { Diesel equipment for waste } \\
\text { placement (excluding soil and sand } \\
\text { extraction) }\end{array}$ & 1.19 & $\mathrm{~L} / \mathrm{Mg}$ & Average estimates based on field data $a^{a, c}$ \\
\hline Heavy equipment & 0.16 & $\mathrm{~kg} / \mathrm{Mg}$ & $\begin{array}{l}\text { Refuse compactor is the predominant } \\
\text { equipment used during operations }{ }^{b}\end{array}$ \\
\hline Heavy equipment haul distance & 80 & $\mathrm{~km}$ & Field data ${ }^{c}$ \\
\hline Fuel haul distance & 402 & $\mathrm{~km}$ & Field data ${ }^{c}$ \\
\hline Soil extraction fuel use & 1.4 & $\mathrm{~L} / \mathrm{Mg}$ soil & Average estimates based on field data $a^{c, c}$ \\
\hline Sand extraction fuel use & 1.8 & $\mathrm{~L} / \mathrm{Mg}$ sand & Average estimates based on field data $a^{c, c}$ \\
\hline
\end{tabular}

${ }^{a}$ The fuel use value in the table is an input estimate describing the average fuel use per Mg of waste corresponding to the equipment use. The hours and types of equipment are reported from sites. Some sites reported hours of heavy equipment use, which was multiplied by the fuel economy (L fuel/hr) of the equipment and then divided by the amount of waste. Other sites directly reported the fuel consumption which was divided by the amount of waste.

${ }^{b}$ The average heavy equipment use per $\mathrm{Mg}$ of waste was calculated based on the average number of hours per $\mathrm{Mg}$ of waste, lifetime of the predominant equipment, and the equipment weight. Heavy equipment use $(\mathrm{kg} / \mathrm{Mg})=[$ hours/Mg waste] / [Lifetime hours/equipment]*[kg/equipment $]$.

${ }^{c}$ Based on the site questionnaire assumptions from the Ecobalance report. ${ }^{4}$

${ }^{d}$ The average value for diesel use was estimated based on the average hours of equipment for $1 \mathrm{Mg}$ soil extraction multiplied by fuel economy (L/hr).

\subsubsection{Final Cover Placement and Closure}

Landfill closure involves the consumption of soil and use of a geomembrane as well as dedicated heavy equipment, all of which contribute to the landfill life cycle inventory. Fuel combusted in construction equipment (e.g., scraper) and in heavy-duty trucks transporting final cover materials is also 
included in the closure module. Figure S5 illustrates the system boundary for the closure module. Table S7 presents the final cover cross section design and other parameters used to calculate the quantities of materials, fuel, and equipment required during the final cover installation.

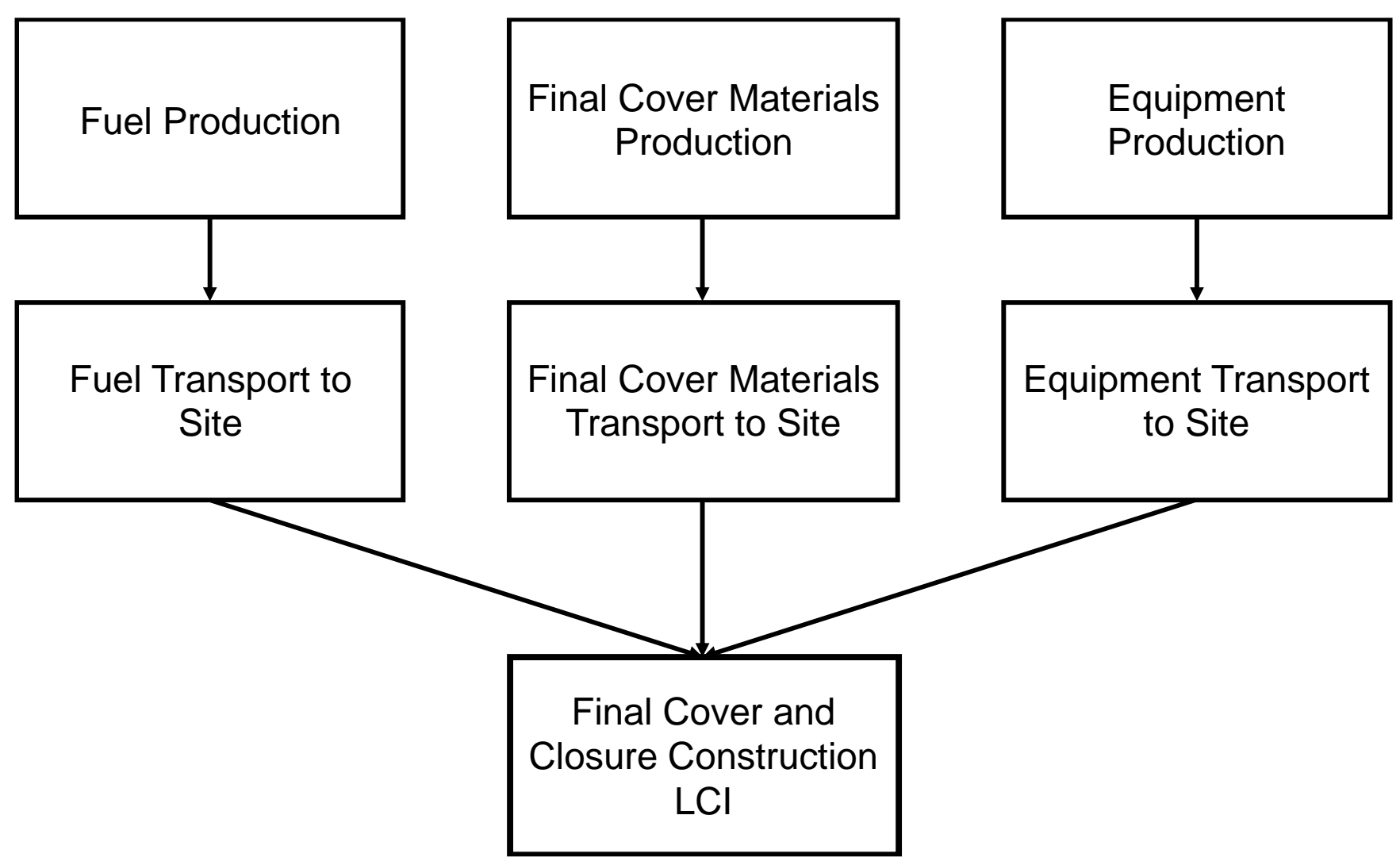

Figure S5. Landfill closure system boundary 
Table S7. Final cover layer thicknesses and other parameters used to model the piping and collection well installation, fuel and heavy equipment used in heavy equipment, and transportation of fuel and materials to the site during the final cover placement and landfill closure.

\begin{tabular}{lrll}
\hline Parameter & Value & Unit & Comment \\
\hline Thickness of topsoil & 0.15 & $\mathrm{~m}$ & \\
Thickness of sand & 0.30 & $\mathrm{~m}$ & \\
Thickness of HDPE layer & 0.0015 & $\mathrm{~m}$ & \\
Thickness of clay & 0.61 & $\mathrm{~m}$ & \\
Heavy equipment use & 0.062 & $\mathrm{~kg} / \mathrm{Mg}$ & Scraper is the predominant equipment $^{a}$ \\
Diesel equipment & 0.067 & $\mathrm{~L} / \mathrm{Mg}$ & Ased during closure $^{a}$ \\
Clay haul distance & 8 & $\mathrm{~km}$ & Field data $^{c}$ \\
Sand haul distance & 32 & $\mathrm{~km}$ & Field data $^{c}$ \\
Heavy equipment haul distance & 402 & $\mathrm{~km}$ & Field data $^{c}$ \\
HDPE (liners and pipes) haul & 402 & $\mathrm{~km}$ & Field data $^{c}$ \\
distance & & & \\
PVC pipes haul distance & 402 & $\mathrm{~km}$ & Field data $^{c}$ \\
Fuel haul distance & 80 & $\mathrm{~km}$ & Field data $^{c}$ \\
\hline
\end{tabular}

${ }^{a}$ The average heavy equipment use per $\mathrm{Mg}$ of waste was calculated based on the average number of hours per $\mathrm{Mg}$ of waste, lifetime of the predominant equipment, and the equipment weight. Heavy equipment use $(\mathrm{kg} / \mathrm{Mg})=[$ hours/Mg waste] / [Lifetime hours/equipment] $*$ [kg/equipment $]$

${ }^{b}$ The fuel use value in the table is an input estimate describing the average fuel use per Mg of waste corresponding to the equipment use. The hours and types of equipment are based on field data. Some sites reported hours of heavy equipment use, which was multiplied by the fuel economy (L fuel/hr) of the equipment and then divided by the amount of waste. Other sites directly reported the fuel consumption which were divided by the amount of waste.

${ }^{c}$ Based on the site questionnaire assumptions from the Ecobalance report. ${ }^{4}$

\subsubsection{Post-Closure Care}

The post-closure care phase involves the maintenance and replacement of the final cover over a 30-year post-closure monitoring period (default time) (Table S8). The life cycle inventory of the postclosure care module includes production of the final cover materials that are used to replace a fraction of the cover over time as well as the fuel consumed in a light-duty truck for inspections and in equipment for cutting vegetation. The replacement of the final cover materials and the heavy equipment use were assumed as a percentage (10\%) of landfill closure LCI (Table S8). 


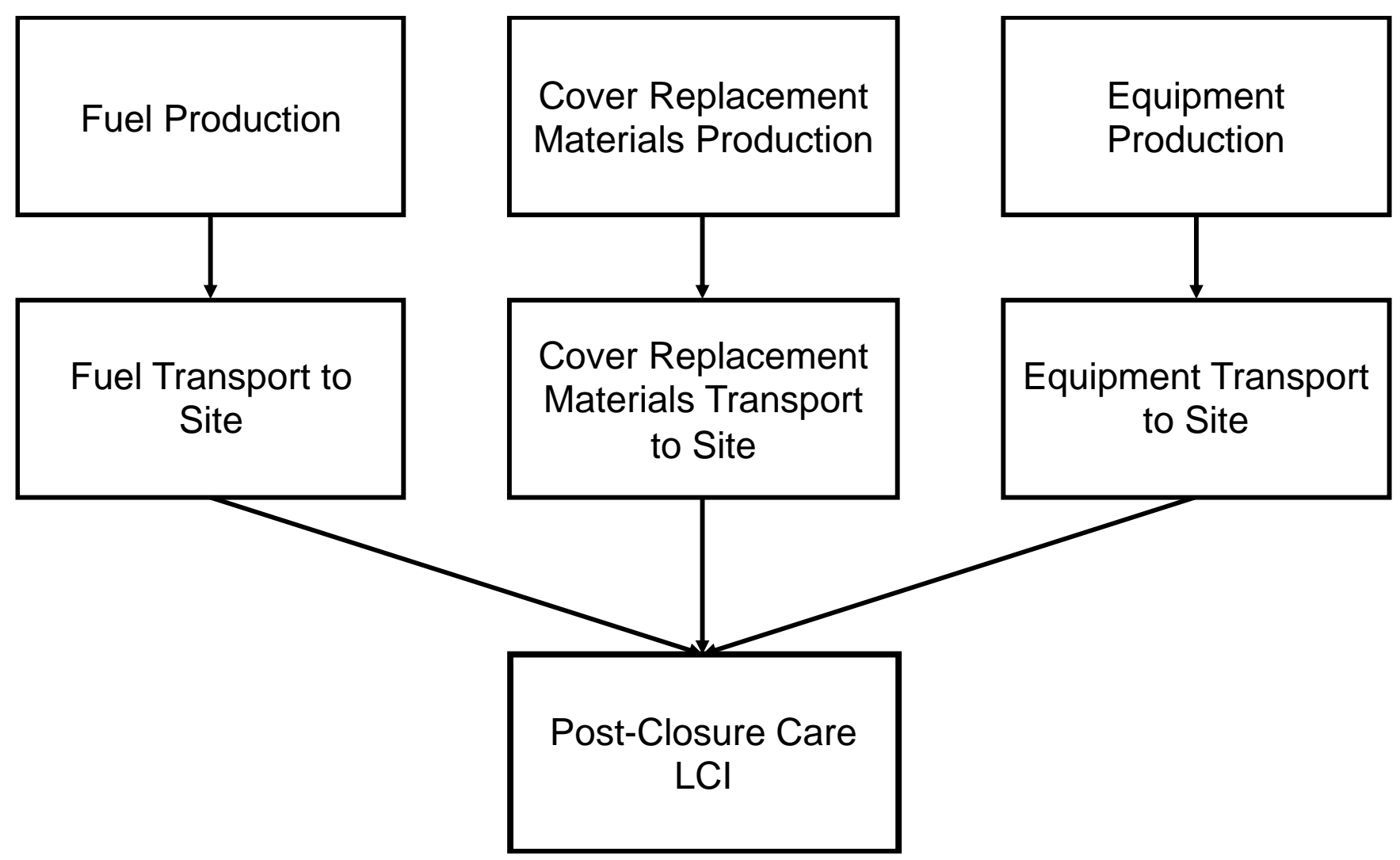

Figure S6. Post-closure care system boundary

Table S8. Timeframe, fuel use, and percentage of cover replacement during the post-closure care period.

\begin{tabular}{lcll}
\hline Parameter & Value & Unit & Comment \\
\hline Diesel equipment & $2.08 \mathrm{E}-05$ & $\mathrm{~L} / \mathrm{Mg}-\mathrm{yr}$ & $\begin{array}{l}\text { Fuel required for inspection and } \\
\text { mowing vegetation }\end{array}$ \\
Post-closure care period & $30 \quad$ years & $\begin{array}{l}\text { Based on U.S. EPA Subtitle D } \\
\text { regulations }\end{array}$ \\
$\begin{array}{l}\text { Percentage of cover materials replaced } \\
\text { over the post-closure period }\end{array}$ & $10 \%$ & $\begin{array}{l}\text { The uses of cover materials, fuel, } \\
\text { and equipment are based on this } \\
\text { percentage applied to those } \\
\text { consumed in the closure system. }\end{array}$ \\
\hline
\end{tabular}

\subsubsection{Summary of Capital Goods Inventory}

The quantity of materials consumed in construction, operation, closure, and post-closure care were quantified using the parameters in Tables Table S2Table S8 and summarized in Table S9. Fuel and electricity as well as transportation that are typically based on field data are also summarized in Table S9. Capital goods inventory was used to estimate the emissions from the extraction and production of materials, fuel, electricity, and transportation. 
Table S9. Summary of intermediate calculations (e.g., land surface area and volume of waste buried) for materials, fuel, and electricity used for the construction, operation, closure, and post-closure care phases of the landfill life cycle. The capital goods quantities estimated are based on $1 \mathrm{Mg}$ of waste buried in a 'large' landfill that has a mean annual waste acceptance of $233,091 \mathrm{Mg} / \mathrm{yr}$ and a 80 -yr operating years, as defined in the main body Modeling Approach.

\begin{tabular}{|c|c|c|c|}
\hline Process & Intermediate Calculations & Value & Unit \\
\hline Landfill Design & Volume of waste capacity & $17,460,000$ & $\mathrm{~m}^{3}$ \\
\hline Landfill Design & Volume of available waste disposal & $19,206,000$ & $\mathrm{~m}^{3}$ \\
\hline Landfill Design & Mass of waste capacity & $18,647,280$ & $\mathrm{Mg}$ \\
\hline Landfill Design & Depth of liner and leachate system & 1.22 & $\mathrm{~m}$ \\
\hline Landfill Design & Depth of final cover & 1.07 & $\mathrm{~m}$ \\
\hline Landfill Design & Height of waste above the grade & 59.89 & $\mathrm{~m}$ \\
\hline Landfill Design & Height of waste below the grade & 6.40 & $\mathrm{~m}$ \\
\hline Landfill Design & Width of waste disposal volume & 689.56 & $\mathrm{~m}$ \\
\hline Landfill Design & Length of waste disposal volume & 689.56 & $\mathrm{~m}$ \\
\hline Landfill Design & Landfill area covered by waste & $475,491.72$ & $\mathrm{~m}^{2}$ \\
\hline Landfill Design & Bottom landfill length & 643.84 & $\mathrm{~m}$ \\
\hline Landfill Design & Top landfill length & 323.80 & $\mathrm{~m}$ \\
\hline Landfill Design & Bottom waste length (considering liners depth) & 636.51 & $\mathrm{~m}$ \\
\hline Landfill Design & Top waste length (considering liners depth) & 317.39 & $\mathrm{~m}$ \\
\hline Landfill Design & Area of bottom including side slopes & 466,823 & $\mathrm{~m}^{2}$ \\
\hline Landfill Design & Area of top including side slopes & 480,055 & $\mathrm{~m}^{2}$ \\
\hline Construction & Volume of clay used in the liner & 284,575 & $\mathrm{~m}^{3}$ \\
\hline Construction & Volume of sand used in the liner & 256,11 & $\mathrm{~m}^{3}$ \\
\hline Construction & Volume of gravel used in the drainage & $28,457.518$ & $\mathrm{~m}^{3}$ \\
\hline Construction & Volume of HDPE used in the liner & 711 & $\mathrm{~m}^{3}$ \\
\hline Construction & Mass of clay liner per Mg waste & 28.11 & $\mathrm{~kg} / \mathrm{Mg}$ \\
\hline Construction & Mass of sand liner per Mg waste & 21.45 & $\mathrm{~kg} / \mathrm{Mg}$ \\
\hline Construction & Mass of gravel liner per $\mathrm{Mg}$ waste & 2.32 & $\mathrm{~kg} / \mathrm{Mg}$ \\
\hline Construction & Mass of HDPE liner per Mg waste & 0.04 & $\mathrm{~kg} / \mathrm{Mg}$ \\
\hline Construction & Side length & 20.24 & $\mathrm{~m}$ \\
\hline Construction & $\begin{array}{l}\text { Number of rows of pipes in the leachate collection } \\
\text { systems (LCS) }\end{array}$ & 22.00 & pipes \\
\hline Construction & Number of rows of branches pipes in the LCS & 22.00 & branch pipes \\
\hline Construction & Length of header pipe & 1,273 & $\mathrm{~m}$ \\
\hline Construction & Length of bottom and side pipes & 16,549 & $\mathrm{~m}$ \\
\hline Construction & Length of branches pipes & 14,894 & $\mathrm{~m}$ \\
\hline Construction & Total length of pipe & 32,716 & $\mathrm{~m}$ \\
\hline Construction & Length of HDPE pipe per $\mathrm{Mg}$ waste in LCS & 0.0018 & $\mathrm{~m} / \mathrm{Mg}$ \\
\hline Construction & Length of PVC pipe per Mg waste in LCS & 0.0000 & $\mathrm{~m} / \mathrm{Mg}$ \\
\hline Construction & Number of vertical gas wells & 117 & wells \\
\hline Construction & Number of wells across landfill width & 11 & wells \\
\hline Construction & $\begin{array}{l}\text { Length of HDPE pipe per Mg waste in gas collection } \\
\text { and control system (GCCS) }\end{array}$ & 0.00044 & $\mathrm{~m} / \mathrm{Mg}$ \\
\hline
\end{tabular}




\begin{tabular}{|c|c|c|c|}
\hline Process & Intermediate Calculations & Value & Unit \\
\hline Construction & Mass of vertical PVC wells per Mg waste in GCCS & 0.0011 & $\mathrm{~kg} / \mathrm{Mg}$ \\
\hline Construction & Heavy equipment during landfill construction & 0.02 & $\mathrm{~kg} / \mathrm{Mg}$ \\
\hline Construction & Asphalt used for landfill construction & 0.09 & $\mathrm{~kg} / \mathrm{Mg}$ \\
\hline Construction & Concrete used for leachate sumps & 0.01 & $\mathrm{~kg} / \mathrm{Mg}$ \\
\hline Construction & Fuel used for heavy equipment during construction & 0.30 & $\mathrm{~L} / \mathrm{Mg}$ \\
\hline Construction & $\begin{array}{l}\text { Transport fuel and other materials (HDPE, PVC, } \\
\text { heavy equipment, concrete, asphalt) }\end{array}$ & 51.78 & $\mathrm{~kg}-\mathrm{km} / \mathrm{Mg}$ \\
\hline Construction & $\begin{array}{l}\text { Transport fuel and other materials (HDPE, PVC, } \\
\text { heavy equipment, concrete, asphalt) }\end{array}$ & 0.0017 & $\mathrm{v}-\mathrm{km} / \mathrm{Mg}$ \\
\hline Construction & Transport soil, clay and/or sand/gravel & 985.64 & $\mathrm{~kg}-\mathrm{km} / \mathrm{Mg}$ \\
\hline Construction & Transport soil, clay and/or sand/gravel & 0.04 & $\mathrm{v}-\mathrm{km} / \mathrm{Mg}$ \\
\hline Final Cover \& Closure & Volume of topsoil used in the cover & 73,160 & $\mathrm{~m}^{3}$ \\
\hline Final Cover \& Closure & Volume of sand used in the cover & 146,321 & $\mathrm{~m}^{3}$ \\
\hline Final Cover \& Closure & Volume of HDPE used in the cover & 732 & $\mathrm{~m}^{3}$ \\
\hline Final Cover \& Closure & Volume of clay used in the cover & 292,642 & $\mathrm{~m}^{3}$ \\
\hline Final Cover \& Closure & Mass of soil per Mg waste & 7.23 & $\mathrm{~kg} / \mathrm{Mg}$ \\
\hline Final Cover \& Closure & Mass of sand per Mg waste & 12.26 & $\mathrm{~kg} / \mathrm{Mg}$ \\
\hline Final Cover \& Closure & Mass of HDPE per Mg waste & 0.04 & $\mathrm{~kg} / \mathrm{Mg}$ \\
\hline Final Cover \& Closure & Mass of clay per Mg waste & 28.91 & $\mathrm{~kg} / \mathrm{Mg}$ \\
\hline Final Cover \& Closure & $\begin{array}{l}\text { Heavy equipment used for heavy equipment during } \\
\text { closure }\end{array}$ & 0.06 & $\mathrm{~kg} / \mathrm{Mg}$ \\
\hline Final Cover \& Closure & Fuel used for heavy equipment during closure & 0.140 & $\mathrm{~L} / \mathrm{Mg}$ \\
\hline Final Cover \& Closure & $\begin{array}{l}\text { Transport fuel and other materials (HDPE, PVC, } \\
\text { heavy equipment, concrete, asphalt) }\end{array}$ & 50.73 & $\mathrm{~kg}-\mathrm{km} / \mathrm{Mg}$ \\
\hline Final Cover \& Closure & $\begin{array}{l}\text { Transport fuel and other materials (HDPE, PVC, } \\
\text { heavy equipment, concrete, asphalt) }\end{array}$ & 0.0017 & $\mathrm{v}-\mathrm{km} / \mathrm{Mg}$ \\
\hline Final Cover \& Closure & Transport soil, clay and/or sand/gravel & 623.47 & $\mathrm{~kg}-\mathrm{km} / \mathrm{Mg}$ \\
\hline Final Cover \& Closure & Transport soil, clay and/or sand/gravel & 0.03 & $\mathrm{v}-\mathrm{km} / \mathrm{Mg}$ \\
\hline Waste Placement Operations & Electricity used for office and maintenance buildings & 0.08 & $\mathrm{kWh} / \mathrm{Mg}$ \\
\hline Waste Placement Operations & Heavy equipment used during waste placement & 0.16 & $\mathrm{~kg} / \mathrm{Mg}$ \\
\hline Waste Placement Operations & Fuel used for heavy equipment during operation & 1.19 & $\mathrm{~L} / \mathrm{Mg}$ \\
\hline Waste Placement Operations & $\begin{array}{l}\text { Transport fuel and other materials (HDPE, PVC, } \\
\text { heavy equipment, concrete, asphalt) }\end{array}$ & 414.64 & $\mathrm{~kg}-\mathrm{km} / \mathrm{Mg}$ \\
\hline Waste Placement Operations & $\begin{array}{l}\text { Transport fuel and other materials (HDPE, PVC, } \\
\text { heavy equipment, concrete, asphalt) }\end{array}$ & 0.01 & $\mathrm{v}-\mathrm{km} / \mathrm{Mg}$ \\
\hline Post-Closure Care & Mass of soil replaced annually & 0.02 & $\mathrm{~kg} / \mathrm{Mg}-\mathrm{yr}$ \\
\hline Post-Closure Care & Mass of sand replaced annually & 0.04 & $\mathrm{~kg} / \mathrm{Mg}-\mathrm{yr}$ \\
\hline Post-Closure Care & Mass of HDPE replaced annually & 0.0001 & $\mathrm{~kg} / \mathrm{Mg}-\mathrm{yr}$ \\
\hline Post-Closure Care & Mass of clay replaced annually & 0.10 & $\mathrm{~kg} / \mathrm{Mg}-\mathrm{yr}$ \\
\hline Post-Closure Care & $\begin{array}{l}\text { Heavy equipment used during post-closure care } \\
\text { (PCC) }\end{array}$ & 2.07E-04 & $\mathrm{kg} / \mathrm{Mg}-\mathrm{yr}$ \\
\hline Post-Closure Care & Fuel used for heavy equipment during closure & 8.66E-04 & $\mathrm{L} / \mathrm{Mg}$ \\
\hline Post-Closure Care & $\begin{array}{l}\text { Transport fuel and other materials (HDPE, PVC, } \\
\text { heavy equipment, concrete, asphalt) }\end{array}$ & 25.03 & $\mathrm{~kg}-\mathrm{km} / \mathrm{Mg}$ \\
\hline Post-Closure Care & $\begin{array}{l}\text { Transport fuel and other materials (HDPE, PVC, } \\
\text { heavy equipment, concrete, asphalt) }\end{array}$ & 0.0008 & $\mathrm{v}-\mathrm{km} / \mathrm{Mg}$ \\
\hline
\end{tabular}




\begin{tabular}{|c|c|c|c|}
\hline Process & Intermediate Calculations & Value & Unit \\
\hline Post-Closure Care & Transport soil, clay and/or sand/gravel & 2.08 & $\mathrm{~kg}-\mathrm{km} / \mathrm{Mg}$ \\
\hline Post-Closure Care & Transport soil, clay and/or sand/gravel & 0.0001 & $\mathrm{v}-\mathrm{km} / \mathrm{Mg}$ \\
\hline
\end{tabular}

Table S10. Final life-cycle inventory of materials, electricity, fuel uses, and transportation based on 1 $\mathrm{Mg}$ of waste buried in a 'large' landfill that has a mean annual waste acceptance of $233,091 \mathrm{Mg} / \mathrm{yr}$ and a 80-yr operating years.

\begin{tabular}{llcc}
\hline Activity & Sub-activity & Value & Unit \\
\hline Material Use & Clay & 57.11 & $\mathrm{~kg} / \mathrm{Mg}$ \\
Material Use & Sand & 33.75 & $\mathrm{~kg} / \mathrm{Mg}$ \\
Material Use & Gravel & 2.32 & $\mathrm{~kg} / \mathrm{Mg}$ \\
Material Use & HDPE liner & 0.074 & $\mathrm{~kg} / \mathrm{Mg}$ \\
Material Use & HDPE Pipe & 0.002 & $\mathrm{~m} / \mathrm{Mg}$ \\
Material Use & PVC Pipe & 0.001 & $\mathrm{~kg} / \mathrm{Mg}$ \\
Material Use & Heavy equipment & 0.238 & $\mathrm{~kg} / \mathrm{Mg}$ \\
Material Use & Asphalt & 0.085 & $\mathrm{~kg} / \mathrm{Mg}$ \\
Material Use & Concrete & 0.007 & $\mathrm{~kg} / \mathrm{Mg}$ \\
Material Use & Soil & 7.25 & $\mathrm{~kg} / \mathrm{Mg}$ \\
Building & Buildings for personnel operating trailer and maintenance & $2.29 \mathrm{E}-05$ & $\mathrm{~m} / \mathrm{Mg}$ \\
Energy Use & Electricity & 0.081 & $\mathrm{kWh} / \mathrm{Mg}$ \\
Fuel Use & Diesel equipment & 1.63 & $\mathrm{~L} / \mathrm{Mg}$ \\
Transportation & Heavy-load heavy duty truck, full run & 542.98 & $\mathrm{~kg}-\mathrm{km} / \mathrm{Mg}$ \\
Transportation & Heavy-load heavy duty truck, empty run & 0.018 & $\mathrm{v}-\mathrm{km} / \mathrm{Mg}$ \\
Transportation & Medium-load heavy duty truck, full run & 1,611 & $\mathrm{~kg}-\mathrm{km} / \mathrm{Mg}$ \\
Transportation & Medium-load heavy duty truck, empty run & 0.067 & $\mathrm{v}-\mathrm{km} / \mathrm{Mg}$ \\
\hline
\end{tabular}

${ }^{a} \mathrm{v}-\mathrm{km}=$ vehicle-kilometers travelled

\subsection{Landfill Gas Generation, Collection, and Control}

\subsubsection{Landfill Gas Generation}

The U.S. EPA's Landfill Gas Emissions Model (LandGEM) ${ }^{6}$ is widely used in practice for predicting methane generation in the U.S., and it was adopted for this model (Eq. (S1)):

$$
Q_{n}=k L_{0} \sum_{i=0}^{n} \sum_{j=0.0}^{0.9} \frac{M_{i}}{10} e^{-k t_{i, j}}
$$

where $Q_{n}$ is the $\mathrm{CH}_{4}$ generation rate $\left(\mathrm{m}^{3} \mathrm{yr}^{-1}\right)$ in year $n ; k$ is first-order waste decay rate $\left(\mathrm{yr}^{-1}\right) ; L_{0}$ is the $\mathrm{CH}_{4}$ generation potential $\left(\mathrm{m}^{3} \mathrm{Mg}^{-1}\right.$ wet waste); $M_{i}$ is the waste mass placement in year $i(\mathrm{Mg}) ; j$ is an intra-annual time increment used to calculate $\mathrm{CH}_{4}$ generation; and $t$ is time (yr). 


\subsubsection{Landfill Gas Collection}

LFG collection efficiency varies with the timing of waste being buried and the lengths of time that waste has been buried and wait before initial collection, interim or long-term cover, and final cover (Figure S7). A given mass of waste could be buried at different times and we are not sure about when the waste is disposed, and waste buried later in the landfill's life will wait less time to reach improved gas collection than waste buried earlier in the landfill's life. Therefore, the collection efficiencies must be averaged to estimate the fraction of gas collected after an average mass of waste has been buried for a specific period of time (Figure S8 and Figure S9). The gas collection schedule and collection efficiency estimates for each schedule shown in Table S11 were used to calculated a temporally averaged collection efficiency for each year of cell operation after waste burial. The temporally averaged annual collection efficiencies are used to estimate the volume of $\mathrm{CH}_{4}$ collected, flared, combusted for energy, oxidized, and emitted for MSW and each material over 1,000 years, under which $99.99 \%$ of the $\mathrm{CH}_{4}$ emissions has been released at the lowest decay rate of $0.02 \mathrm{yr}^{-1}$.

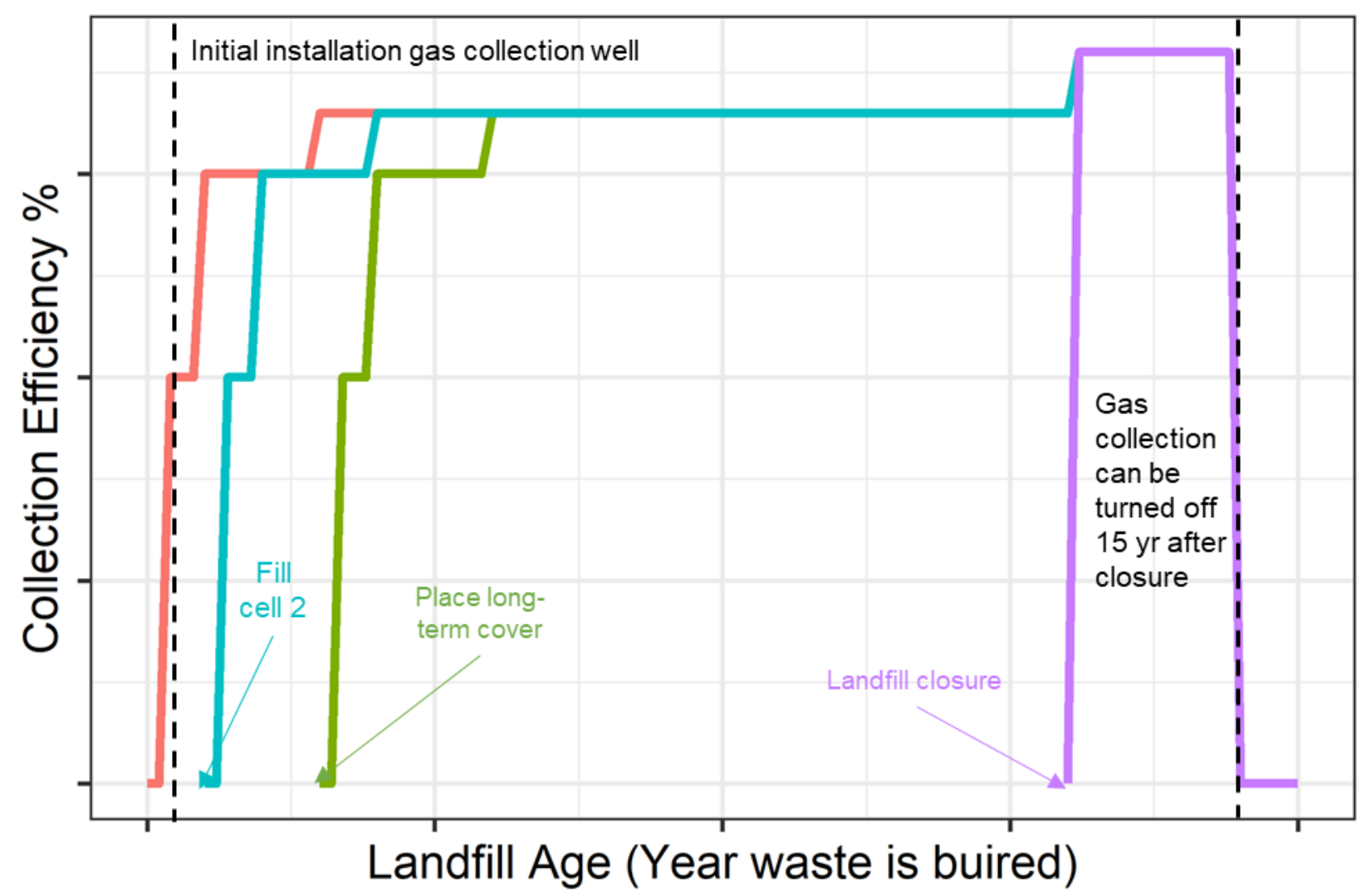

Figure S7. Conceptual diagram for time-varying collection efficiency that depends on the year waste is buried in the cell and waste age. 
Table S11. Landfill Gas Collection Inputs and Landfill Gas Combustion System Parameters Used in the Flare and Energy Recovery Scenarios.

\begin{tabular}{|c|c|c|c|c|}
\hline \multirow[b]{2}{*}{ Parameter } & \multicolumn{3}{|c|}{ Gas collection schedules $^{7,8}$} & \multirow[b]{2}{*}{$\begin{array}{l}\text { Clean Air Act } \\
\text { Minimum }\end{array}$} \\
\hline & Aggressive & CA & $\begin{array}{c}\text { EPA } \\
\text { Typical }\end{array}$ & \\
\hline Time until initial gas collection (yr) & 0.5 & 1 & 2 & 5 \\
\hline Initial gas collection efficiency (\%) & 50 & 50 & 50 & 50 \\
\hline Time to increased gas collection efficiency (yr) & 3 & 2 & 5 & 5 \\
\hline Increased gas collection efficiency (\%) & 75 & 80 & 75 & 75 \\
\hline Time to long term cover since waste burial (yr) & 15 & 15 & 15 & 15 \\
\hline Gas collection efficiency under long term cover (\%) & 82.5 & 85 & 82.5 & 82.5 \\
\hline Time from final waste placement to final cover (yr) & 1 & 1 & 1 & 1 \\
\hline Gas collection efficiency under final cover (\%) & 90 & 90 & 90 & 90 \\
\hline \multicolumn{5}{|l|}{ Flare Inputs } \\
\hline Allowable minimum gas flow rate $\left(\mathrm{m}^{3} \mathrm{~min}^{-1}\right)$ & NA & 2.8 & NA & NA \\
\hline \multicolumn{5}{|c|}{ Nonmethane organic compounds emission rate at which gas collection is turned off ( $\mathrm{NSPS}, 1999): 50 \mathrm{Mg} / \mathrm{yr}$ [34 Mg/yr] } \\
\hline Flare turn-on time $(\mathrm{yr})^{a}$ & 0.5 & 1 & 2 & 5 \\
\hline \multicolumn{5}{|l|}{ Flare turn-off time (yr) by decay rate $(k)^{a}$} \\
\hline$k=0.02 \mathrm{yr}^{-1}$ & 95 [113] & $233[233]$ & 95 [113] & 95 [113] \\
\hline$k=0.04 \mathrm{yr}^{-1}$ & $95[110]$ & $161[161]$ & $95[100]$ & $95[100]$ \\
\hline$k=0.06 \mathrm{yr}^{-1}$ & $95[95]$ & $134[134]$ & $95[95]$ & 95 [95] \\
\hline$k=0.12 \mathrm{yr}^{-1}$ & 95 [95] & $106[106]$ & $95[95]$ & $95[95]$ \\
\hline \multicolumn{5}{|l|}{ Energy Recovery Inputs } \\
\hline $\begin{array}{l}\text { Minimum landfill gas collection required for an energy } \\
\text { recovery project }\left(\mathrm{m}^{3} \mathrm{~min}^{-1}\right)\end{array}$ & 9.9 & 9.9 & 9.9 & 9.9 \\
\hline Energy recovery engine downtime (\%) & 3 & 1 & 3 & 3 \\
\hline \multicolumn{5}{|l|}{ Energy recovery turn-on time (yr) by decay rate $(k)^{a}$} \\
\hline$k=0.02 \mathrm{yr}^{-1}$ & 10 & 9 & 10 & 12 \\
\hline$k=0.04 \mathrm{yr}^{-1}$ & 6 & 5 & 6 & 8 \\
\hline$k=0.06 \mathrm{yr}^{-1}$ & 4 & 4 & 5 & 7 \\
\hline$k=0.12 \mathrm{yr}^{-1}$ & 3 & 3 & 3 & 5 \\
\hline \multicolumn{5}{|l|}{ Energy recovery turn-off time (yr) by decay rate $(k)^{a}$} \\
\hline$k=0.02 \mathrm{yr}^{-1}$ & 170 & 171 & 170 & 170 \\
\hline$k=0.04 \mathrm{yr}^{-1}$ & 128 & 129 & 128 & 128 \\
\hline$k=0.06 \mathrm{yr}^{-1}$ & 112 & 113 & 112 & 112 \\
\hline$k=0.12 \mathrm{yr}^{-1}$ & 95 & 95 & 95 & 106 \\
\hline
\end{tabular}

${ }^{a}$ Gas combustion system turn-on and turn-off times were calculated based on the mean size of the landfill $(233,091 \mathrm{Mg}$ MSW/yr), its operating lifetime ( 80 years), the bulk decay rate, the flare turn-off NMOCs, and the minimum landfill gas rate required to install an energy project. 

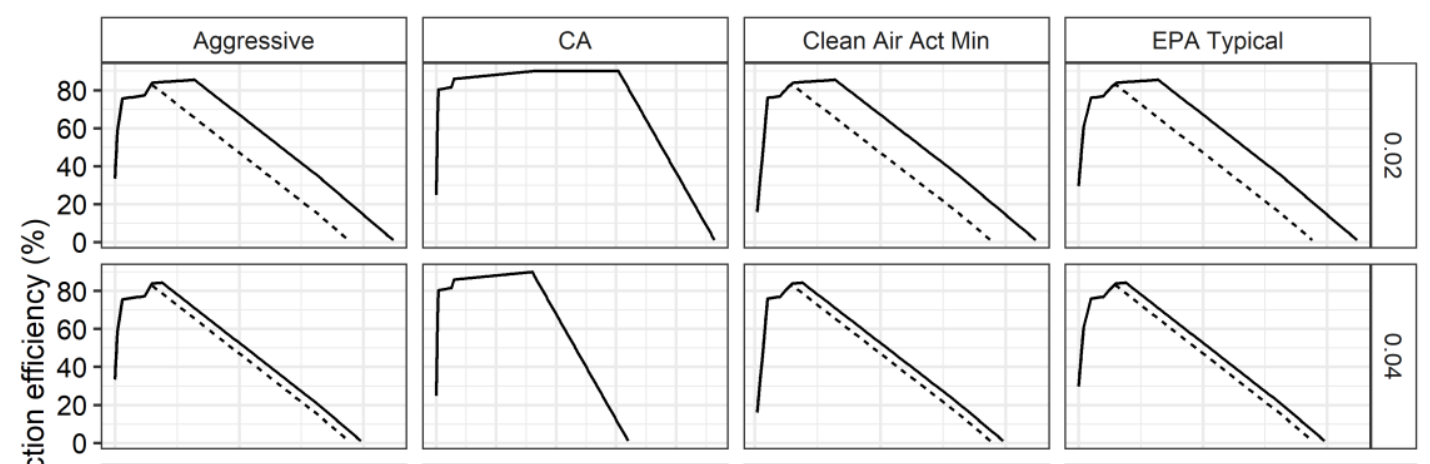

$\operatorname{NMOC}(\mathrm{Mg} / \mathrm{yr})$
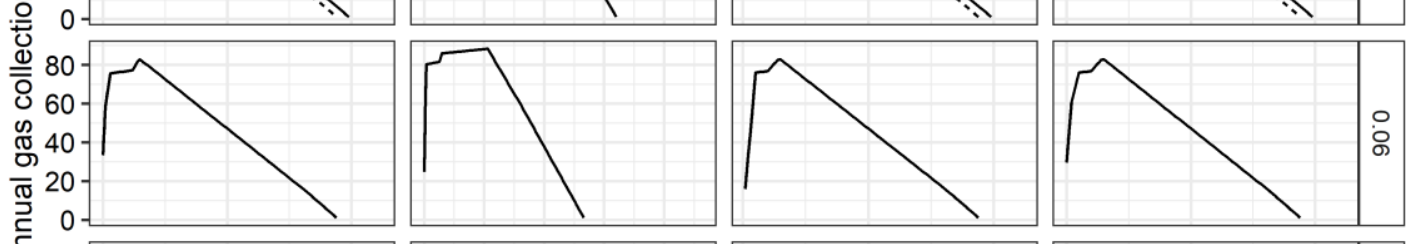

- 34

… 50
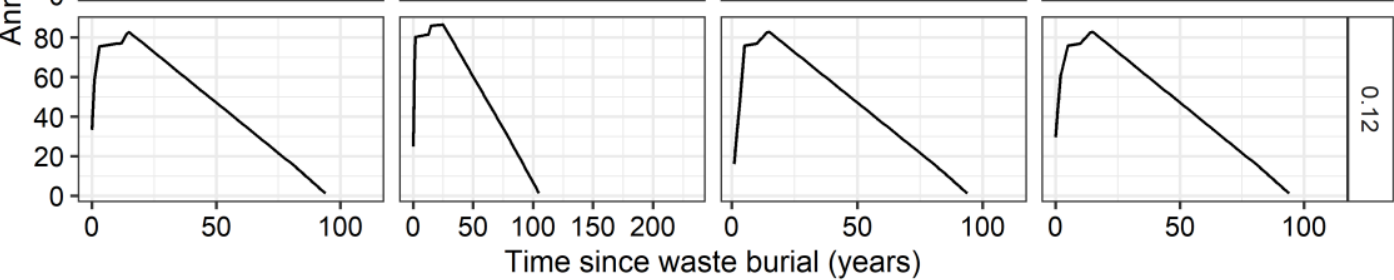

Figure S8. Temporally averaged annual gas collection efficiency for the flare scenario across four gas collection schedules, four decay rate constants, and NMOC thresholds. The turn-on and turn-off times of gas collection and control system were calculated across all scenarios for the mean landfill size and operating life (Table S11). Collection efficiency of zero indicates that the gas collection system has been turned off.

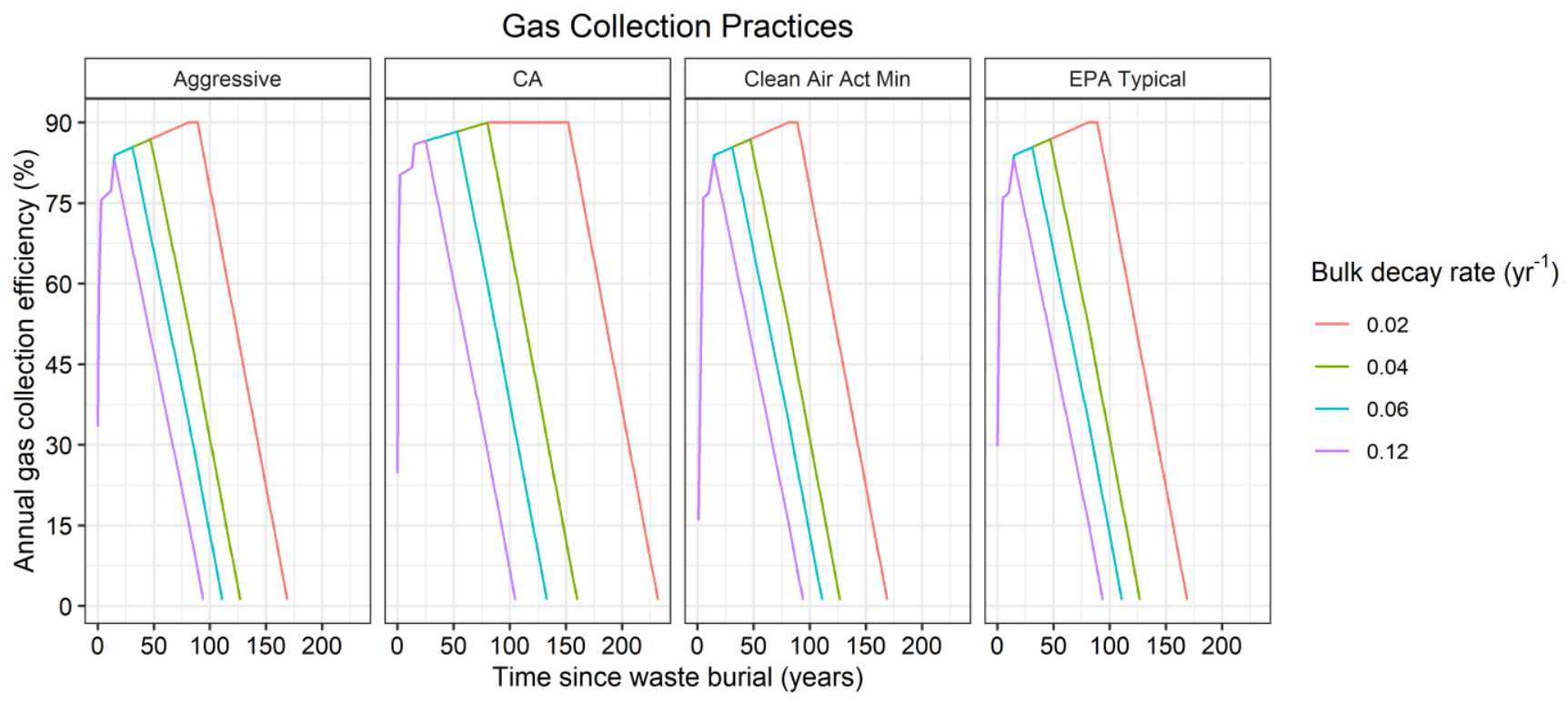

Figure S9. Temporally averaged annual gas collection efficiency for the energy recovery scenario across four gas collection schedules and four decay rate constants. The turn-on and turn-off times for the gas collection and control system were calculated across all scenarios for the mean landfill size and 
operating life (Table S11). NMOC regulations do not affect the timing of installation and turnoff of the gas collection system with energy recovery.

\subsubsection{Waste Component-Specific Properties}

Table S12. Methane Production Potential $\left(\mathrm{L}_{0}\right)$ and Field Decay Rate for Eight MSW Components ${ }^{a}$

\begin{tabular}{lccccc}
\hline \multirow{2}{*}{ Waste Material } & $\mathrm{L}_{0}$ & \multicolumn{3}{c}{ Field decay rate derived from bulk MSW decay rate $(k)$} \\
\cline { 2 - 5 } & $\left(\mathrm{m}^{3} \mathrm{CH}_{4} / \mathrm{wet} \mathrm{Mg}\right)$ & $k=0.02 \mathrm{yr}^{-1}$ & $k=0.04 \mathrm{yr}^{-1}$ & $k=0.06 \mathrm{yr}^{-1}$ & $k=0.12 \mathrm{yr}^{-1}$ \\
\hline Leaves & 40.4 & 0.057 & 0.114 & 0.171 & 0.343 \\
Vegetables & 84.9 & 0.048 & 0.096 & 0.144 & 0.289 \\
Wood & 12.2 & 0.021 & 0.042 & 0.063 & 0.125 \\
Textiles & 80.9 & 0.010 & 0.020 & 0.030 & 0.059 \\
Newsprint & 64.7 & 0.011 & 0.022 & 0.033 & 0.066 \\
Corrugated & 162.9 & 0.007 & 0.013 & 0.020 & 0.039 \\
Cardboard & 240.5 & 0.010 & 0.020 & 0.030 & 0.059 \\
Office Paper & 124.0 & 0.010 & 0.021 & 0.031 & 0.063 \\
Mixed Paper & 100.0 & 0.020 & 0.040 & 0.060 & 0.120 \\
Mixed MSW & & &
\end{tabular}

${ }^{a}$ Values are adopted from De la Cruz and Barlaz (2010). ${ }^{9}$

\subsection{Landfill Leachate Generation}

The volume of leachate is calculated as a percentage of precipitation, which is dependent on the cover type and varies with time (Table S13). As the model is based on $1 \mathrm{Mg}$ of MSW, the time-varying leachate generation was estimated for the average mass of waste year over the 80-year life of the landfill as for the time-varying LFG collection efficiency. For example, a 40-year-old landfill could have young cells (e.g., buried for $3 \mathrm{yr}$ ) with intermediate cover only, as well as sections that have final cover. In this case, most leachate will be generated in the younger cell. 


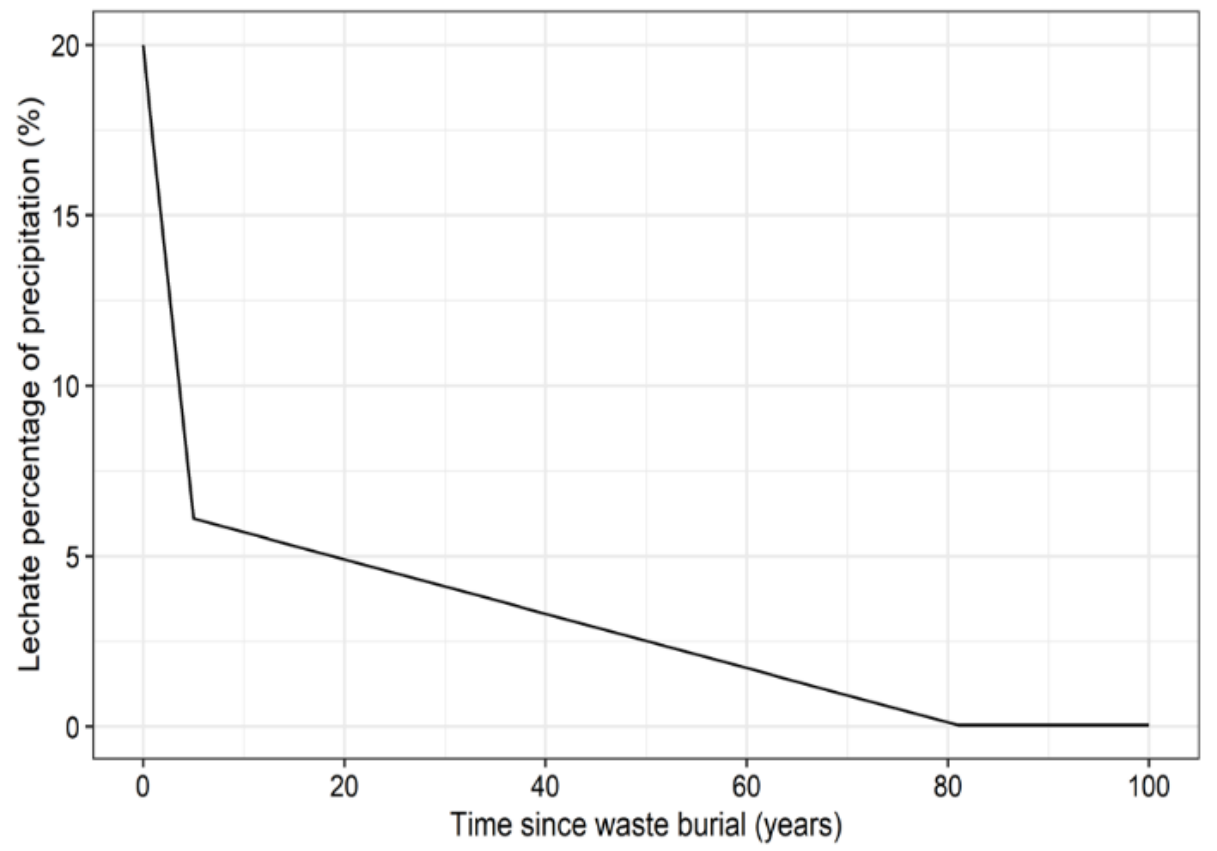

Figure S10. Temporally averaged percentage of precipitation that becomes leachate based on the assumptions in Table S13.

Table S13. Landfill Leachate Generation Rate as a Percentage of Precipitation Varying with Time and Cover Type $^{a}$

\begin{tabular}{lccc}
\hline Parameter & $\begin{array}{c}\text { Time } \\
(\mathbf{y r})\end{array}$ & $\begin{array}{l}\text { \% precipitation } \\
\text { leachate }^{b}\end{array}$ & that becomes \\
\hline $\begin{array}{l}\text { Leachate generation period 1: time to placement } \\
\text { of intermediate cover }\end{array}$ & 5 & $20\left[586 \mathrm{gpad} @ 1000 \mathrm{~mm} / \mathrm{yr} \mathrm{precip}^{c}\right]$ \\
$\begin{array}{l}\text { Leachate generation period 2: years when a } \\
\text { larger fraction of intermediate or final cover is } \\
\text { placed (yr) }\end{array}$ & $6-80$ & $13^{d}\left[380 \mathrm{gpad} @ 1000 \mathrm{~mm} / \mathrm{yr}\right.$ precip $\left.{ }^{c}\right]$ \\
$\begin{array}{l}\text { Leachate generation period 3: years when 100\% } \\
\text { final cover has been placed (yr) }\end{array}$ & $\geq 81$ & $0.4^{e}\left[10 \mathrm{gpad} @ 1000 \mathrm{~mm} / \mathrm{yr} \mathrm{precip}^{c}\right]$ \\
\hline
\end{tabular}

${ }^{a}$ Times in the table are based on the landfill with an expected mean operating life of 80 years. We assumed that waste would be under intermediate cover in year 5 and that final cover would be placed gradually over the landfill life, with final cover placement complete 1 year after landfill closure (Table S11. Landfill Gas Collection Inputs and Landfill Gas Combustion System Parameters Used in the Flare and Energy Recovery Scenarios.Table S11).

${ }^{b}$ Percentage of precipitation that becomes leachate is based on field data. ${ }^{10}$ ${ }^{c}$ gpad $=$ gallon per acre per day. $1 \mathrm{gpad}=1.08 \times 10^{-11} \mathrm{~m} / \mathrm{s}$.

${ }^{d}$ The original source reported that $6.5 \%$ of precipitation becomes leachate when an undefined fraction of intermediated and final covers is present. ${ }^{10}$ This corresponds to $190 \mathrm{gpad}$ at $1000 \mathrm{~mm} / \mathrm{yr}$ precipitation. This is low based on the authors' experience and the default leachate generation rate was doubled. ${ }^{e}$ U.S. EPA reported that the leachate flow rate is approximately $10 \mathrm{gpad}$ within ten years after landfill closure, which corresponds to $0.4 \%$ of $1000 \mathrm{~mm} / \mathrm{yr}$ precipitation that becomes leachate. ${ }^{11}$ 


\section{LIFE CYCLE IMPACT ASSESSMENT}

Table S14. Normalization factors for ten impact categories based on U.S. 2008 according to TRACI v2. $1^{12}$

\begin{tabular}{llll}
\hline Impact Category & Abbv. & Reference Unit (per capita per year) & U.S. 2008 Values \\
\hline Acidification & $\mathrm{ACID}$ & $\mathrm{kg} \mathrm{SO}_{2} \mathrm{eq}$ & 91 \\
Ecotoxicity & $\mathrm{ETOX}$ & $\mathrm{CTU}_{\mathrm{e}}$ & 11076 \\
Eutrophication & $\mathrm{ETP}$ & $\mathrm{kg} \mathrm{N} \mathrm{eq}$ & 22 \\
Global Warming & $\mathrm{GW}$ & $\mathrm{kg} \mathrm{CO}_{2} \mathrm{eq}$ & 24000 \\
Ozone Depletion & $\mathrm{OD}$ & $\mathrm{kg} \mathrm{CFC}-11 \mathrm{eq}$ & 0.16 \\
Photochemical ozone formation & $\mathrm{SMOG}$ & $\mathrm{kg} \mathrm{O}_{3} \mathrm{eq}$ & 1400 \\
Human Health - Cancer & $\mathrm{HHc}$ & $\mathrm{CTU}_{\mathrm{h}}$ & $5.05 \mathrm{E}-05$ \\
Human Health - Non-Cancer & $\mathrm{HHNc}$ & $\mathrm{CTU}_{\mathrm{h}}$ & $1.04 \mathrm{E}-03$ \\
Respiratory effects & $\mathrm{RE}$ & $\mathrm{kg} \mathrm{PM}_{2.5} \mathrm{eq}$ & 24 \\
Fossil Fuel Depletion & $\mathrm{FFD}$ & $\mathrm{MJ} \mathrm{surplus}$ &
\end{tabular}




\section{SUPPLEMENTARY LCA RESULTS}

\subsection{Life-Cycle Impact Results and Major Flow Contributors by Impact Category}

(a) Critical Flow Contributors

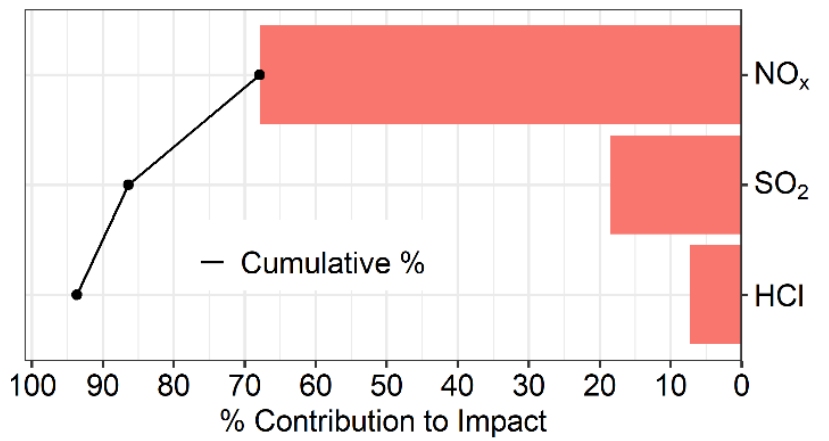

\section{Impact Category: ACID}

(b) Fraction of critical flows from sub-activities

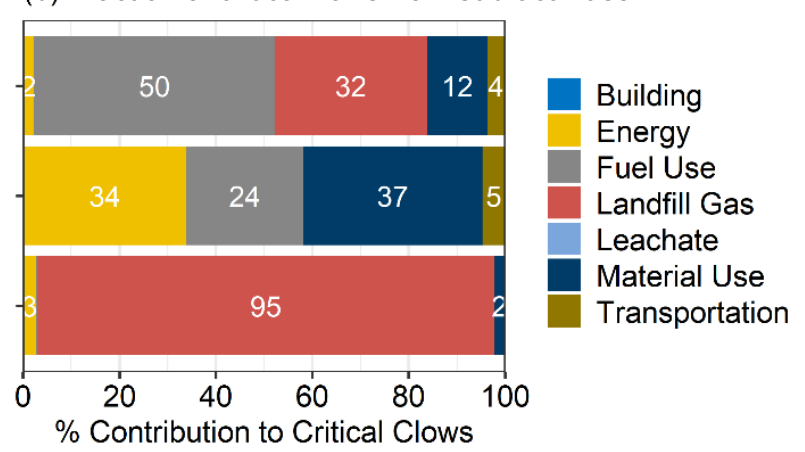

(c) Fraction of critical flows from material use

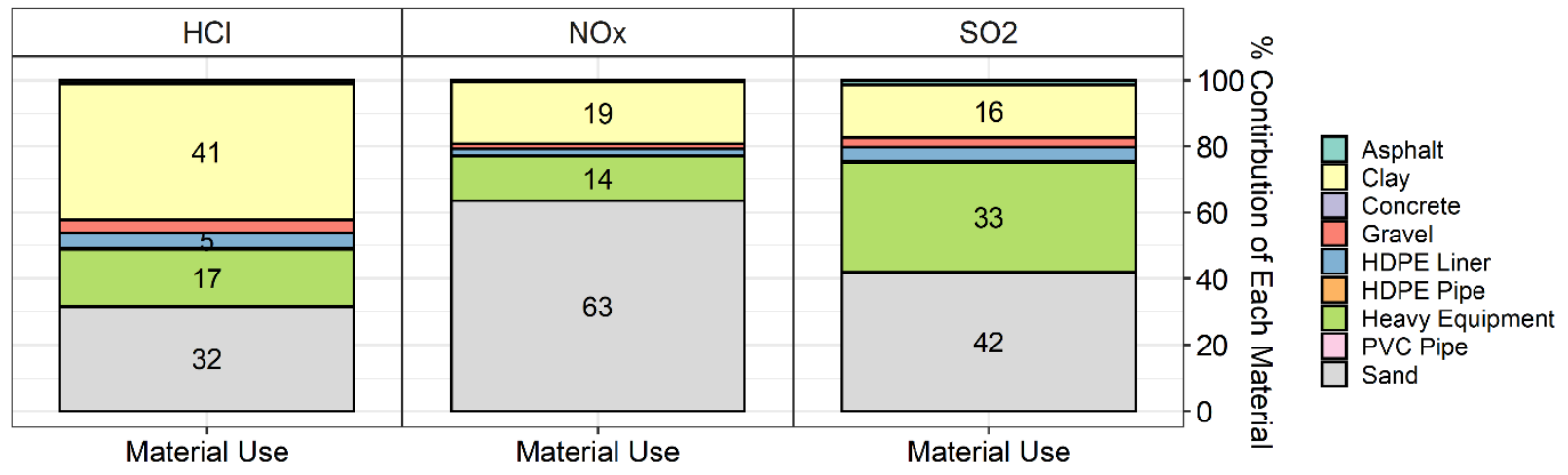

Figure S11. (a) Critical flow contributors that cumulatively contribute $90 \%$ of the acidification (ACID) impact, (b) contribution of critical flows from capital goods and landfill treatment, and (c) contribution of composite materials consumed. 
(a) Critical Flow Contributors

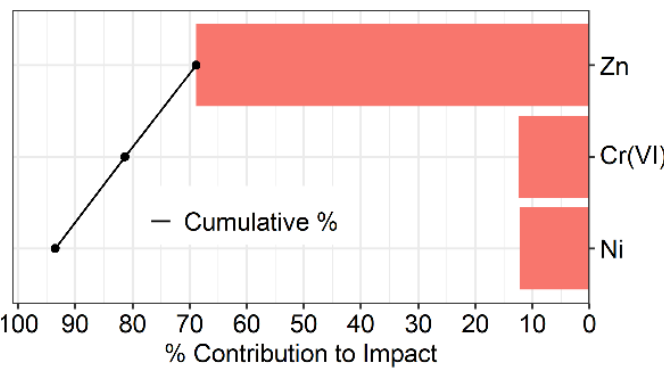

Impact Category: ETOX

(b) Fraction of critical flows from sub-activities

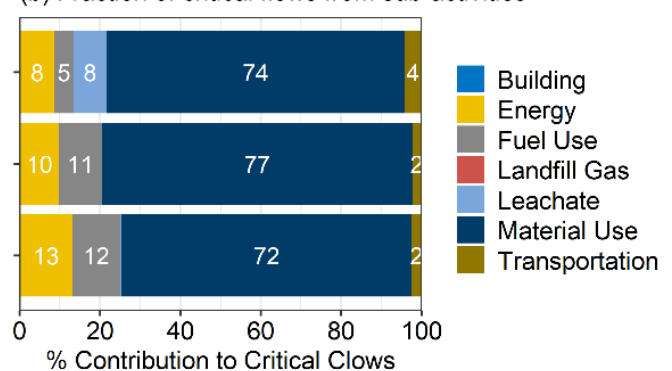

(c) Fraction of critical flows from material use

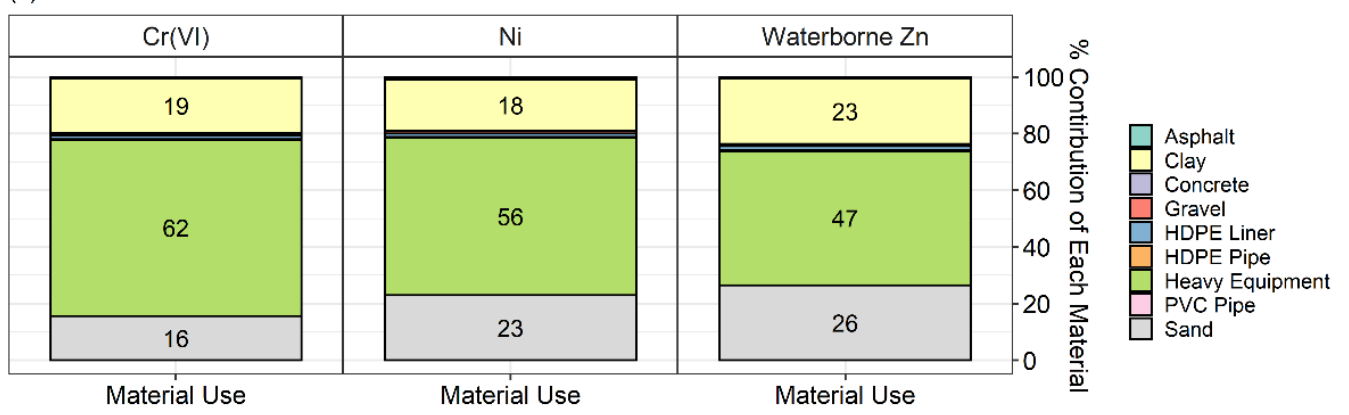

Figure S12. (a) Critical flow contributors that cumulatively contribute $90 \%$ of the ecotoxicity (ETOX) impact, (b) contribution of critical flows from capital goods and landfill treatment, and (c) contribution of composite materials consumed.

\section{Impact Category: ETP}

(a) Critical Flow Contributors

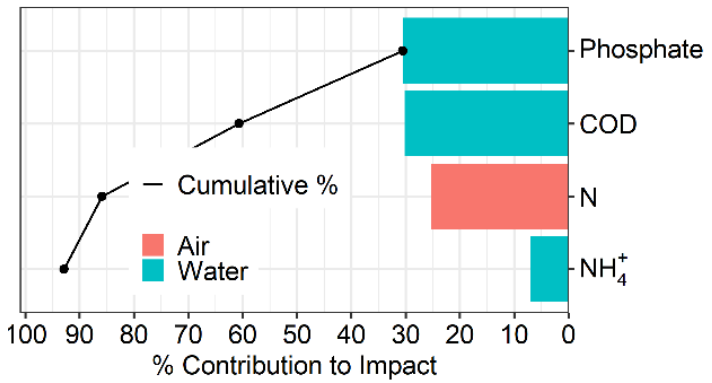

(b) Fraction of critical flows from sub-activities

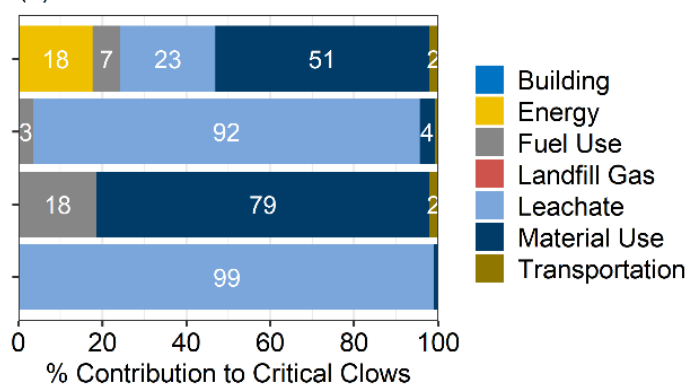

(c) Fraction of critical flows from material use

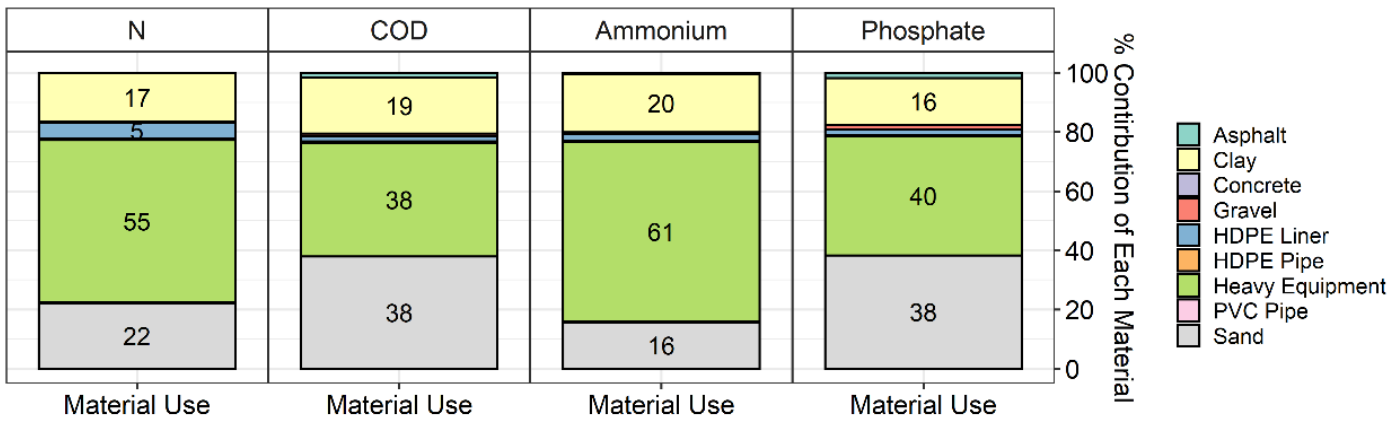

Figure S13. (a) Critical flow contributors that cumulatively contribute $90 \%$ of the eutrophication (ETP) impact, (b) contribution of critical flows from capital goods and landfill treatment, and (c) contribution of composite materials consumed. 


\section{Impact Category: FFD}

(a) Critical Flow Contributors

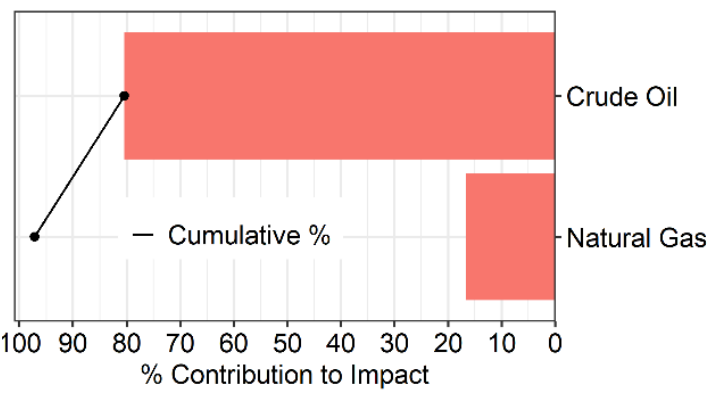

(b) Fraction of critical flows from sub-activities

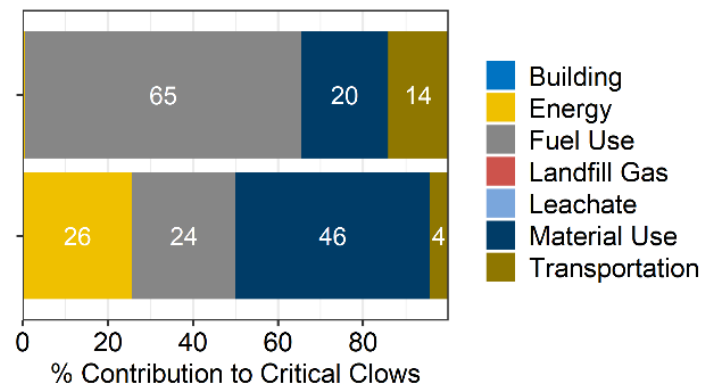

(c) Fraction of critical flows from material use

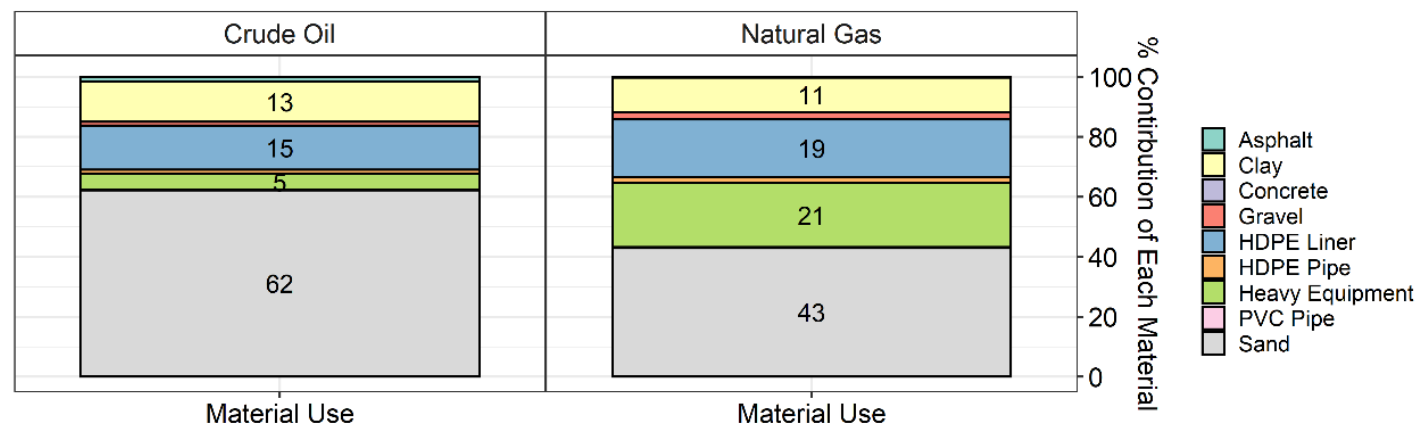

Figure S14. (a) Critical flow contributors that cumulatively contribute $90 \%$ of the fossil fuel depletion (FFD) impact, (b) contribution of critical flows from capital goods and landfill treatment, and (c) contribution of composite materials consumed.

(a) Critical Flow Contributors

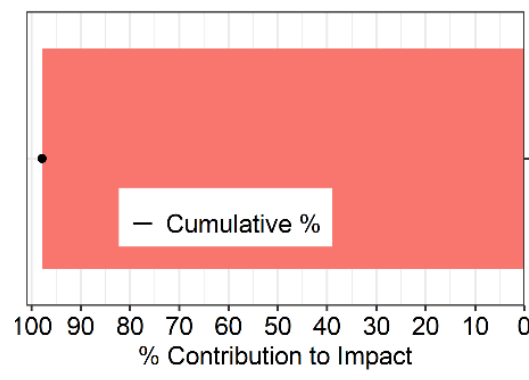

Impact Category: GW

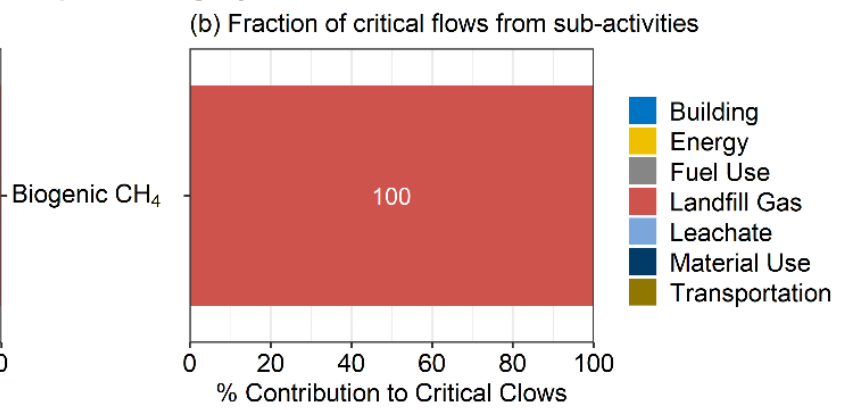

(c) Fraction of critical flows from material use

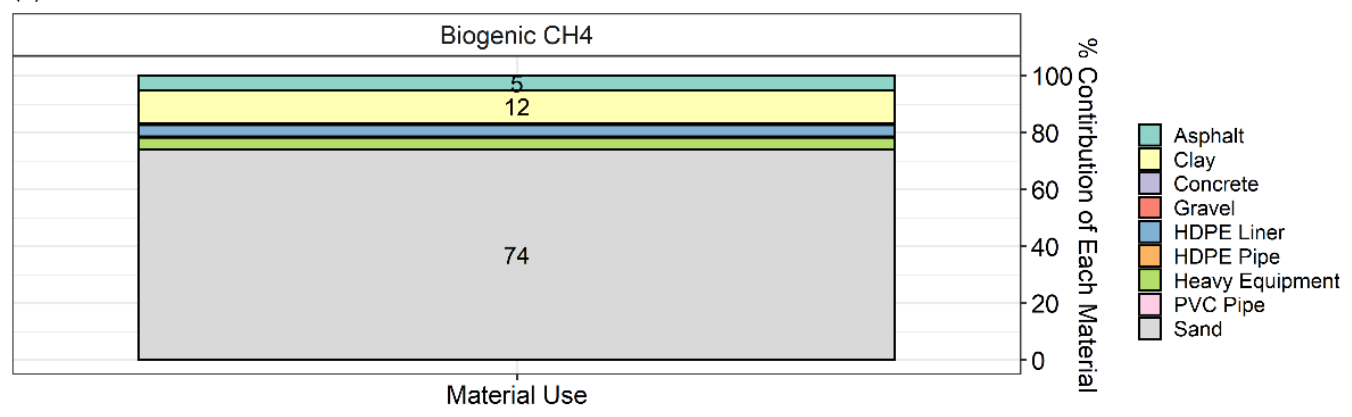

Figure S15. (a) Critical flow contributors that cumulatively contribute $90 \%$ of the global warming (GW) impact, (b) contribution of critical flows from capital goods and landfill treatment, and (c) contribution of composite materials consumed. 
(a) Critical Flow Contributors

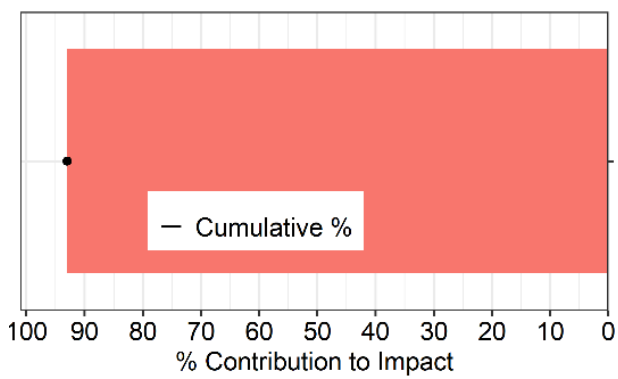

Impact Category: HHc

(b) Fraction of critical flows from sub-activities

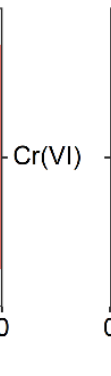

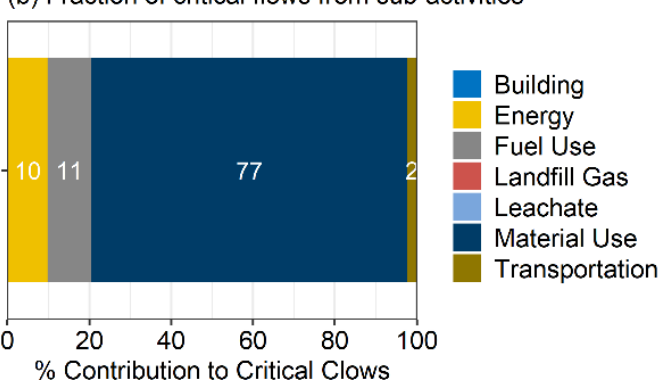

(c) Fraction of critical flows from material use

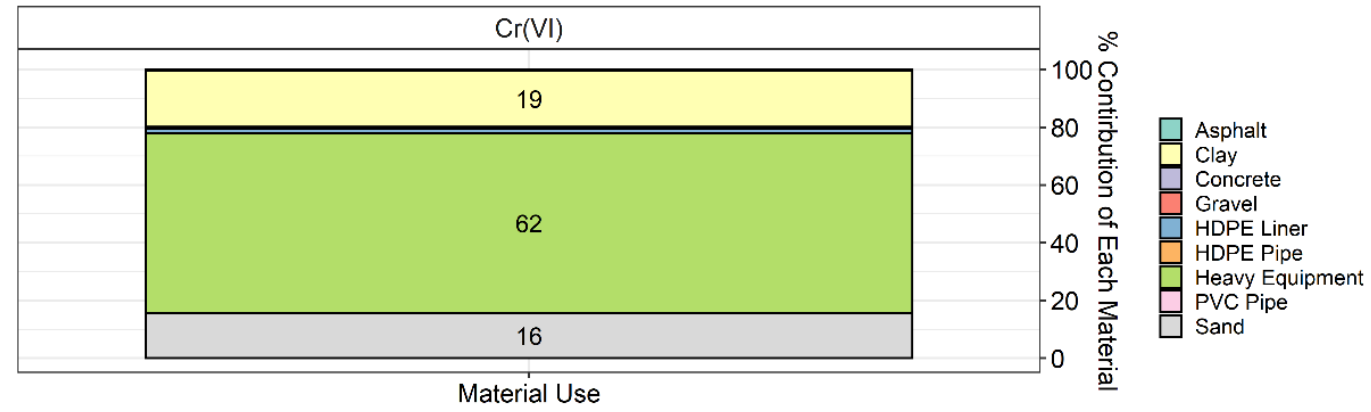

Figure S16. (a) Critical flow contributors that cumulatively contribute $90 \%$ of the human health cancer $(\mathrm{HHc})$ impact, (b) contribution of critical flows from capital goods and landfill treatment, and (c) contribution of composite materials consumed.

\section{Impact Category: HHNc}

(a) Critical Flow Contributors

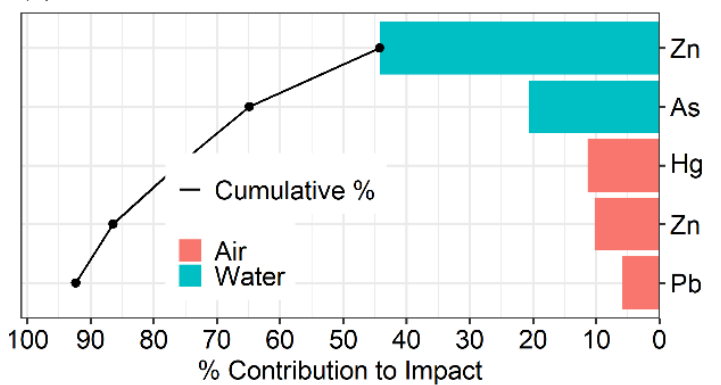

(b) Fraction of critical flows from sub-activities

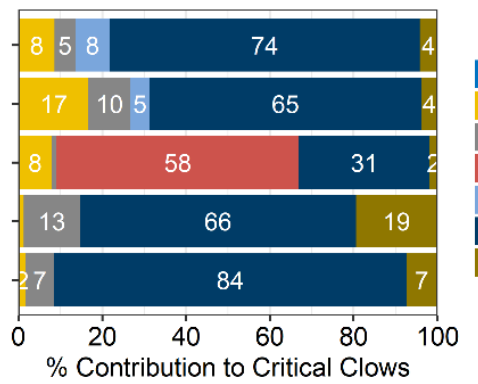

Building

Energy

Fuel Use

Landfill Gas

Leachate

Material Use

Transportation

(c) Fraction of critical flows from material use

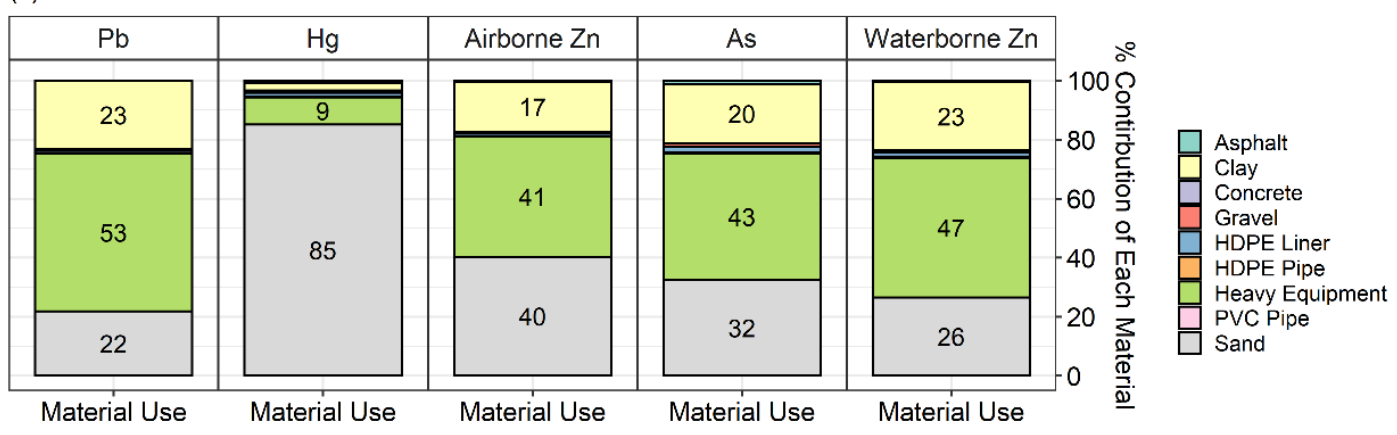

Figure S17. (a) Critical flow contributors that cumulatively contribute $90 \%$ of the human health non-cancer $(\mathrm{HHNc})$ impact, (b) contribution of critical flows from capital goods and landfill treatment, and (c) contribution of composite materials consumed. 


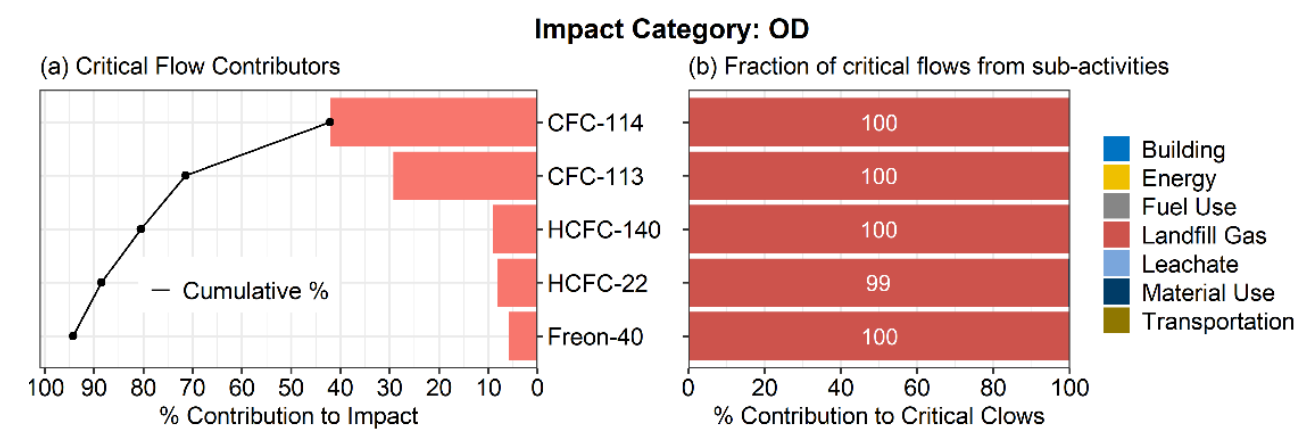

(c) Fraction of critical flows from material use

\begin{tabular}{|c|c|c|c|c|c|c|}
\hline CFC-113 & CFC-114 & Freon-40 & HCFC-140 & HCFC-22 & \multirow{7}{*}{ 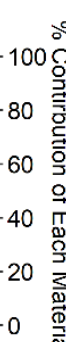 } & \\
\hline \multirow{2}{*}{21} & 7 & $\overline{11}$ & $\overline{11}$ & 15 & & \\
\hline & 12 & 21 & 21 & \multirow{3}{*}{45} & & Asphalt \\
\hline$\frac{1}{5}$ & 12 & & & & & Clay \\
\hline \multirow{2}{*}{30} & \multirow{2}{*}{29} & 18 & 18 & & & Gravel \\
\hline & & 19 & 19 & \multirow[b]{2}{*}{39} & & HDPE Pipe \\
\hline 30 & 35 & 29 & 29 & & & $\begin{array}{l}\text { PVC Pipe } \\
\text { Sand }\end{array}$ \\
\hline Material Us & Material Use & Material Us & Material Use & Material Us & & \\
\hline
\end{tabular}

Figure S18. (a) Critical flow contributors that cumulatively contribute $90 \%$ of the ozone depletion (OD) impact, (b) contribution of critical flows from capital goods and landfill treatment, and (c) contribution of composite materials consumed. The data used to generate this result is the composition of LFG as presented in the U.S. EPA AP-42 database. ${ }^{13}$ The trace organic constituents in LFG in this database are based on LFG composition data from the 1990s and the CFCs likely result from refrigerants in appliances. CFC concentrations have likely decreased over time.

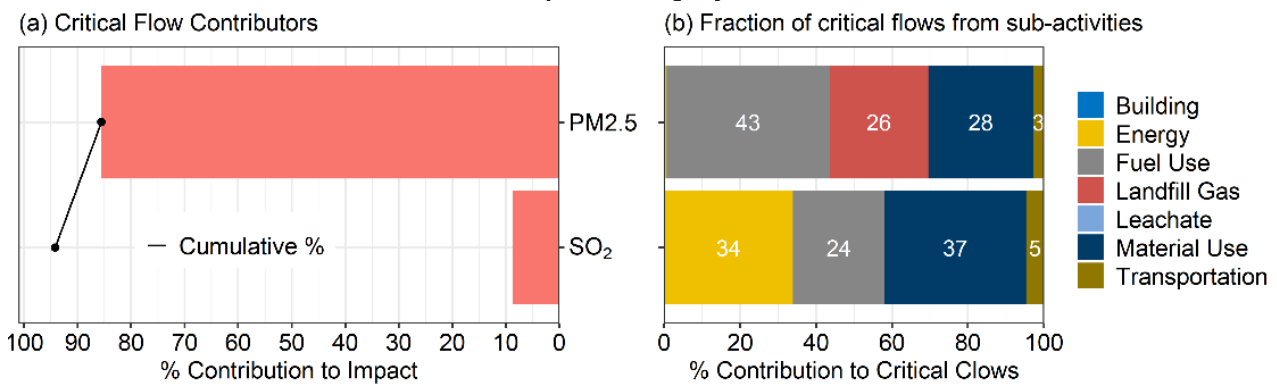

(c) Fraction of critical flows from material use

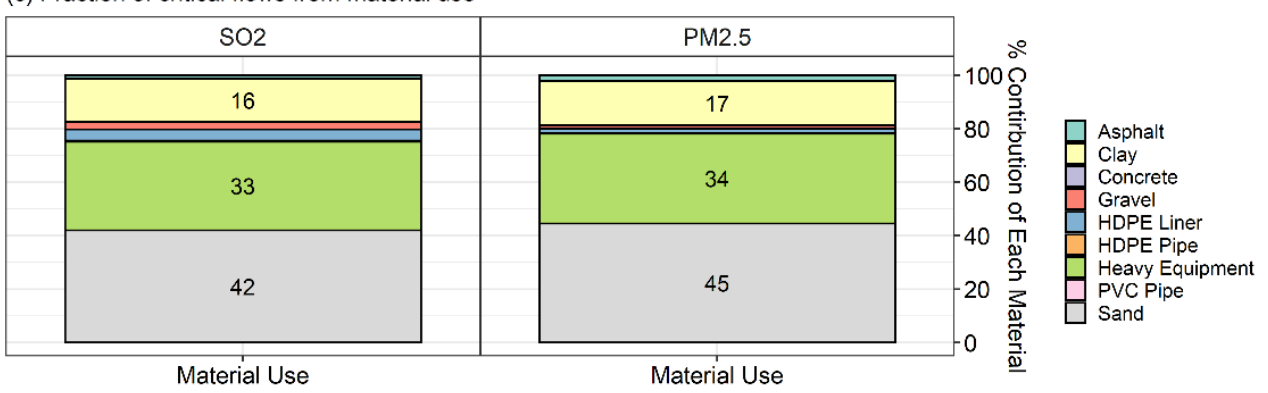

Figure S19. (a) Critical flow contributors that cumulatively contribute $90 \%$ of the respiratory effect (RE), (b) contribution of critical flows from capital goods and landfill treatment, and (c) contribution of composite materials consumed. 


\section{Impact Category: SMOG}

(a) Critical Flow Contributors

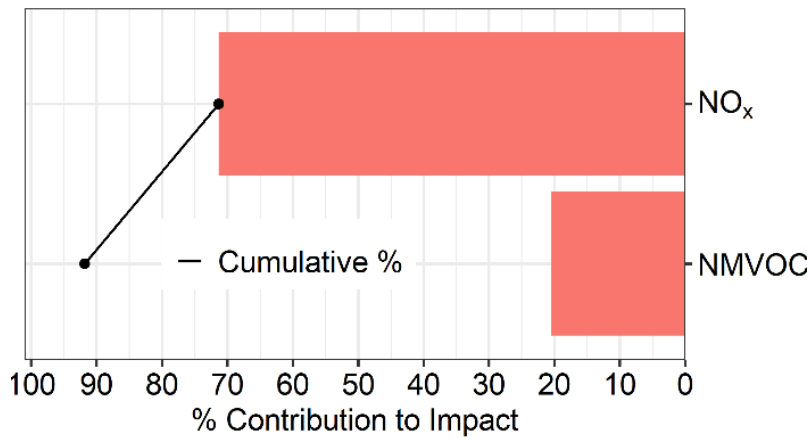

(b) Fraction of critical flows from sub-activities

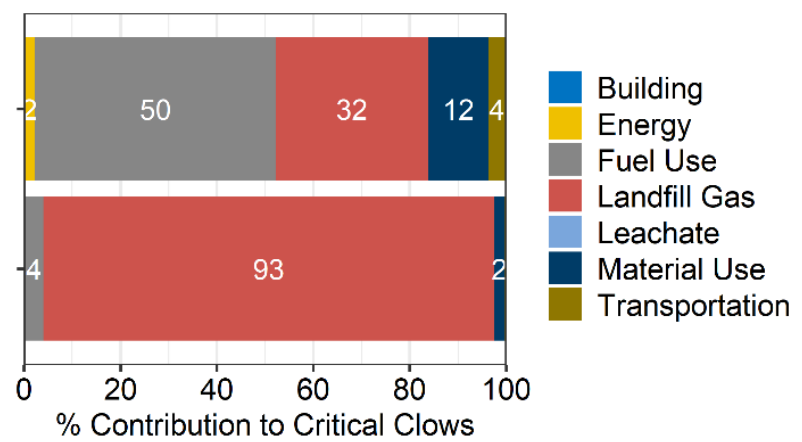

(c) Fraction of critical flows from material use

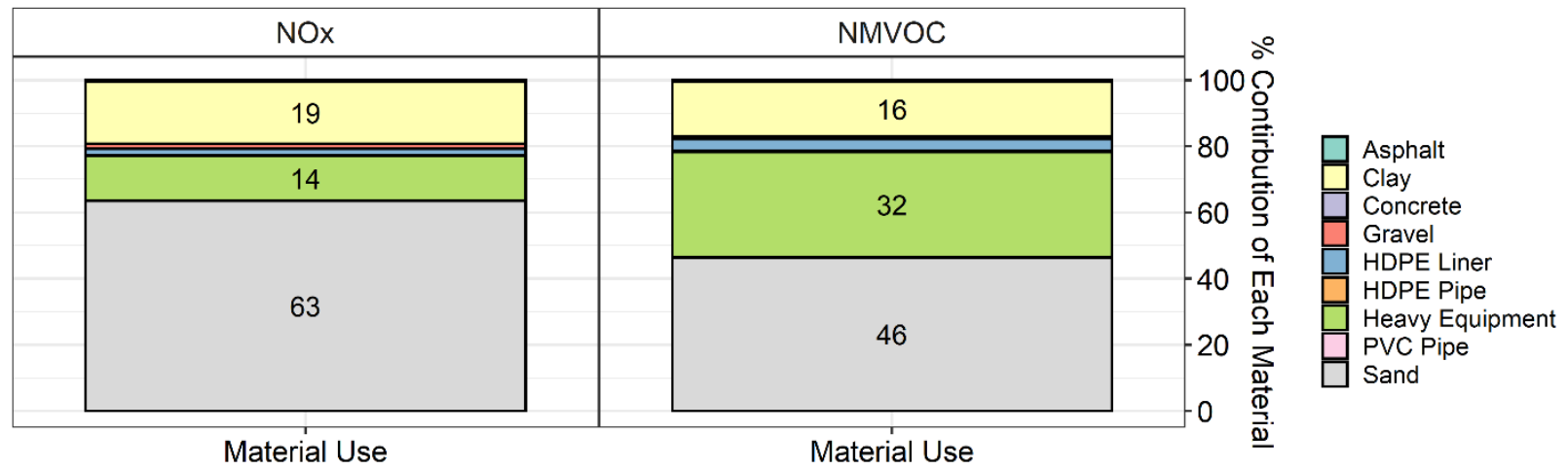

Figure S20. (a) Critical flow contributors that cumulatively contribute $90 \%$ of the smog (SMOG), (b) contribution of critical flows from capital goods and landfill treatment, and (c) contribution of composite materials consumed. 
(a) Normalized Impacts, Electricity Recovery

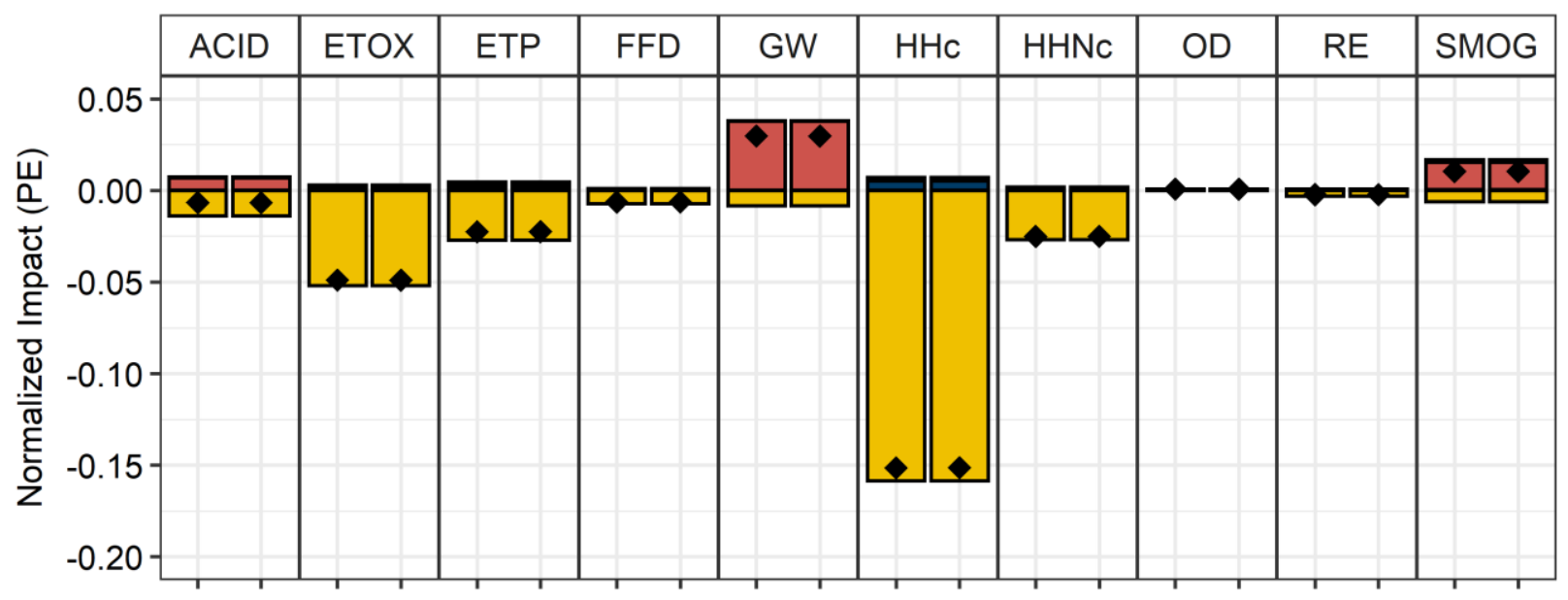

(b) Contribution of Sub-activity to Normalized Impacts, Electricity Recovery

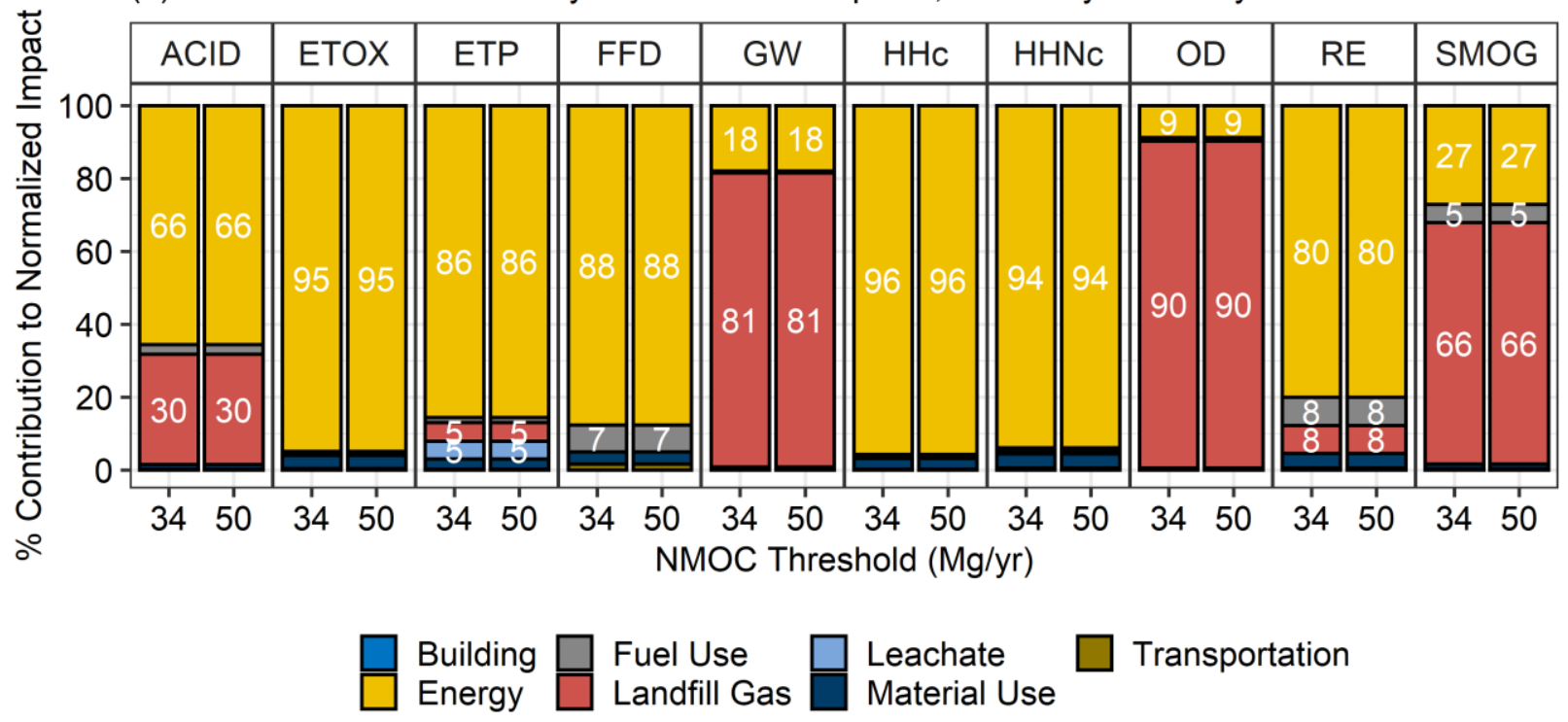

Figure S21. (a) Normalized impacts as person equivalent (PE) and (b) contributions of capital goods and landfill gas and leachate emissions for the electricity recovery scenarios with the EPA Typical collection across two NMOCs threshold for gas regulation and ten impact categories. The landfill was considered with the mean size and operating life across original range of U.S. landfills, accepting 233,000 Mg of MSW per year and operating for 80 years. 


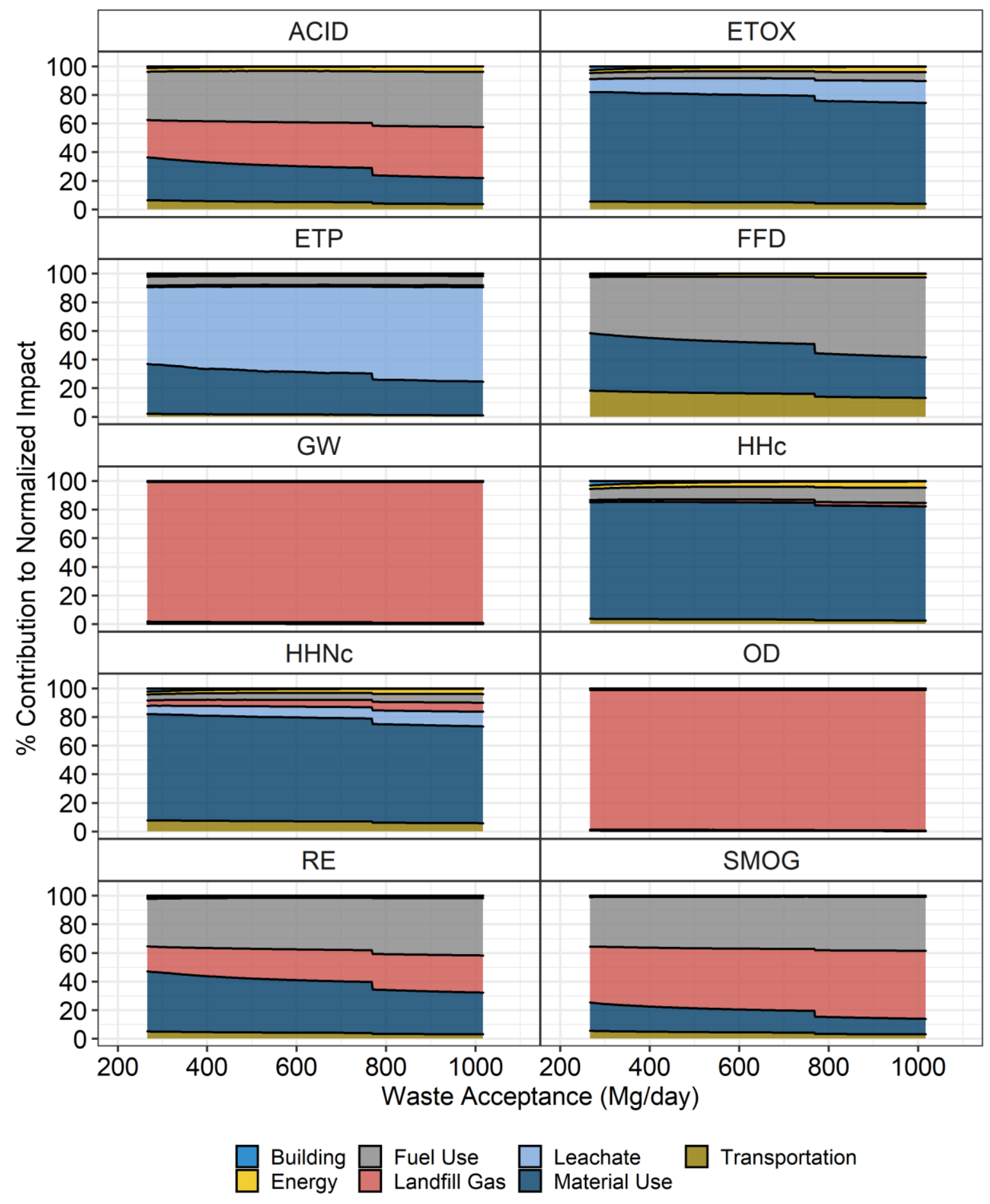

Figure S22. Contributions of capital goods (electricity, fuel, material, transportation) and landfill gas and leachate emissions across ten impact categories based on the flare scenario and EPA Typical collection schedule, given the $1^{\text {st }}$ to $3^{\text {rd }}$ quantile range of landfill size (260 to $1020 \mathrm{Mg} /$ day, as presented in Table S1) for the flare scenario and EPA typical collection schedule. There is a step change at $\sim 770 \mathrm{Mg} \mathrm{day}^{-1}$ that is selected to separate the small and large landfills' design crosssections (Figure 1). 


\subsection{Landfill Methane Profile}
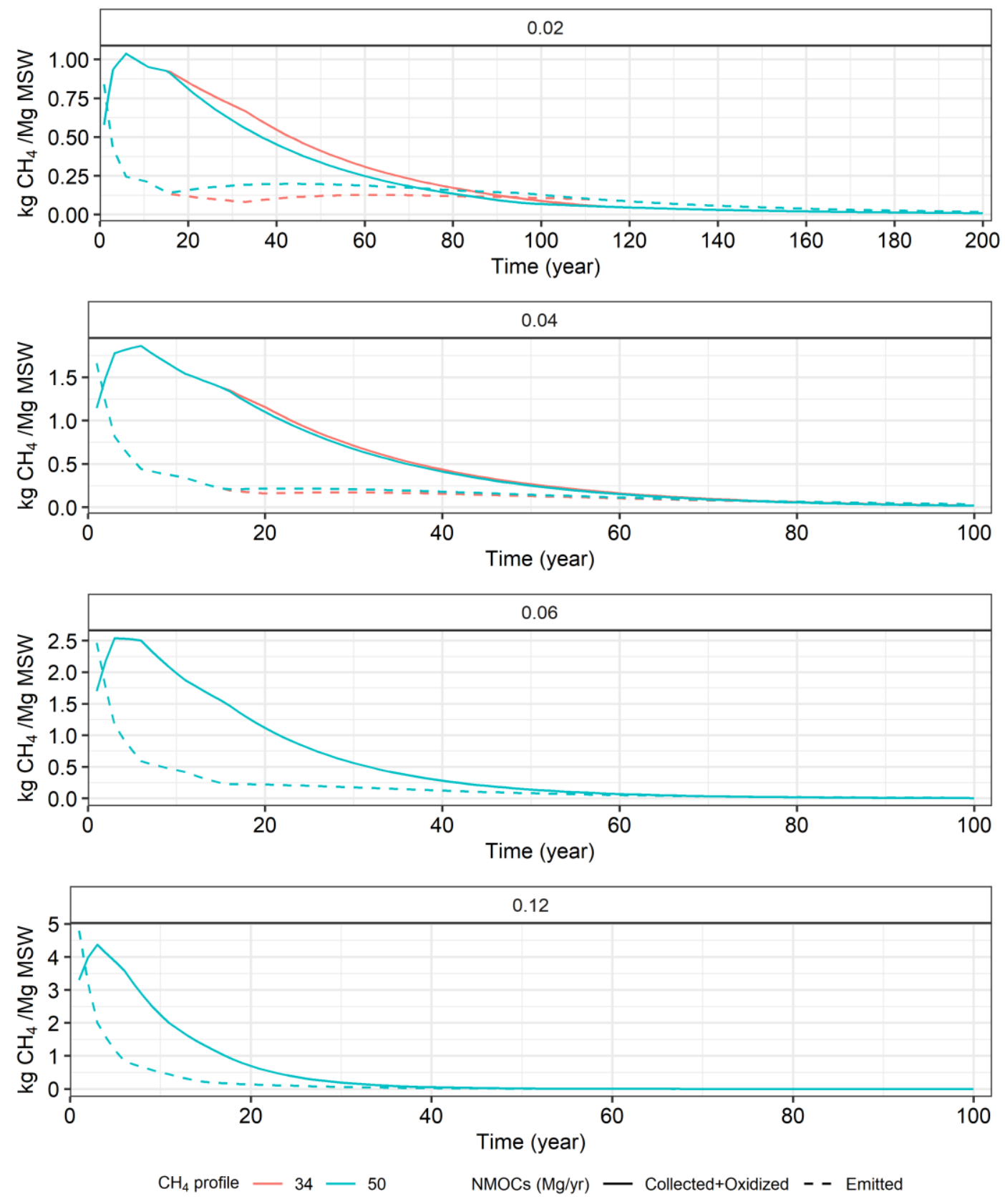

Figure S23. Landfill methane inventory that is collected and flared, oxidized, and emitted based on the flare scenarios and EPA Typical collection across five landfill types (i.e., four decay rate constants and the representative landfill that is a composite of four decay rates) and two flare turnoff NMOCs thresholds. At decay rates of 0.06 and $0.12 \mathrm{yr}^{-1}$, two NMOC lines are overlapped and thus one is invisible. The landfill was considered with the mean size and operating life across original range of U.S. landfills, accepting 233,000 Mg of MSW per year and operating for 80 years. 

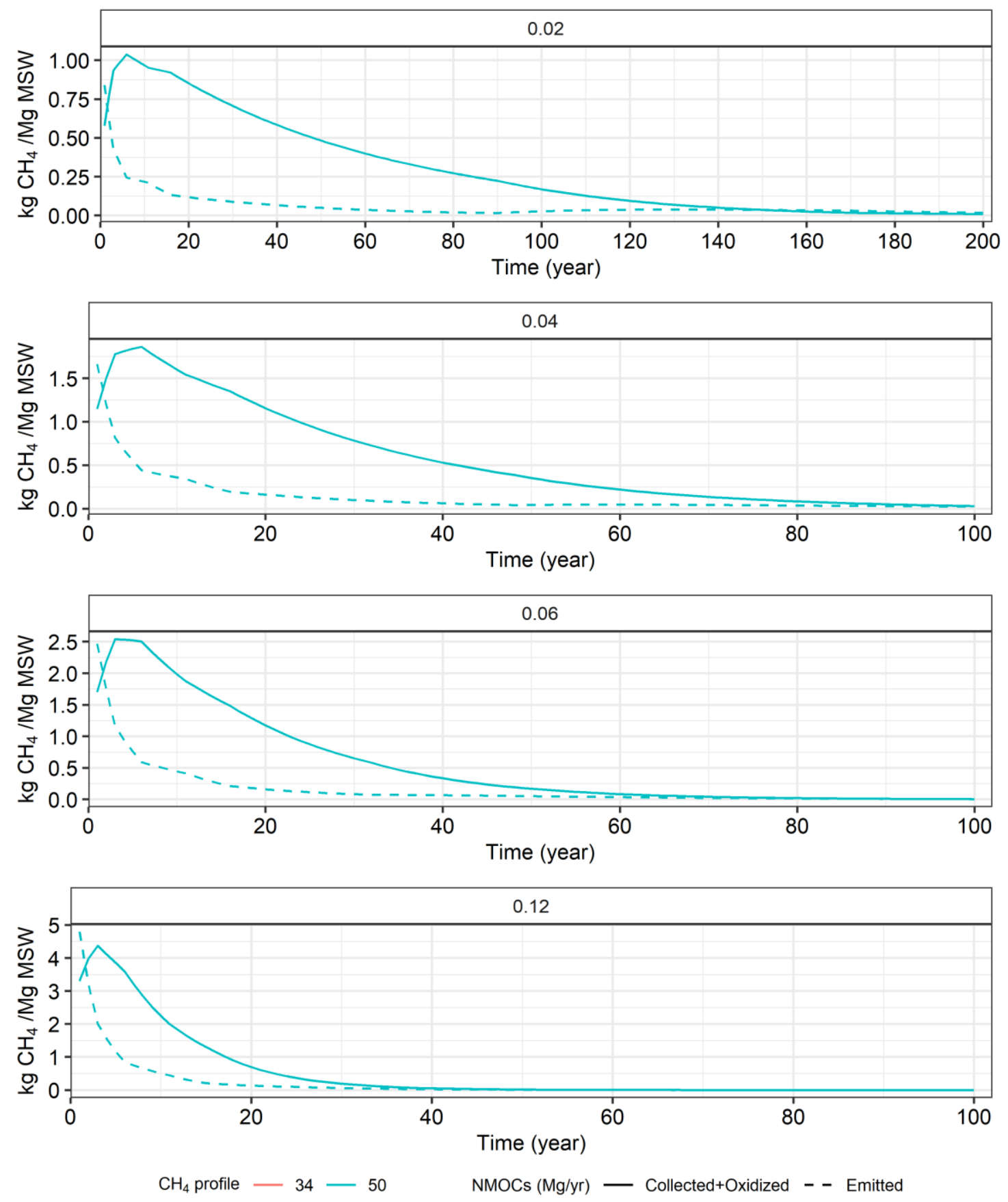

Figure S24. Landfill methane inventory that is collected and flared, oxidized, and emitted based on the electricity recovery scenarios and EPA Typical collection across five landfill types (i.e., four decay rate constants and the representative landfill that is a composite of four decay rates) and two flare turnoff NMOCs thresholds. The stricter NMOC thresholds do not affect the collection performance of energy recovery scenarios and thus two NMOC lines are overlapped. The landfill was considered with the mean size and operating life across original range of U.S. landfills, accepting 233,000 Mg of MSW per year and operating for 80 years. 

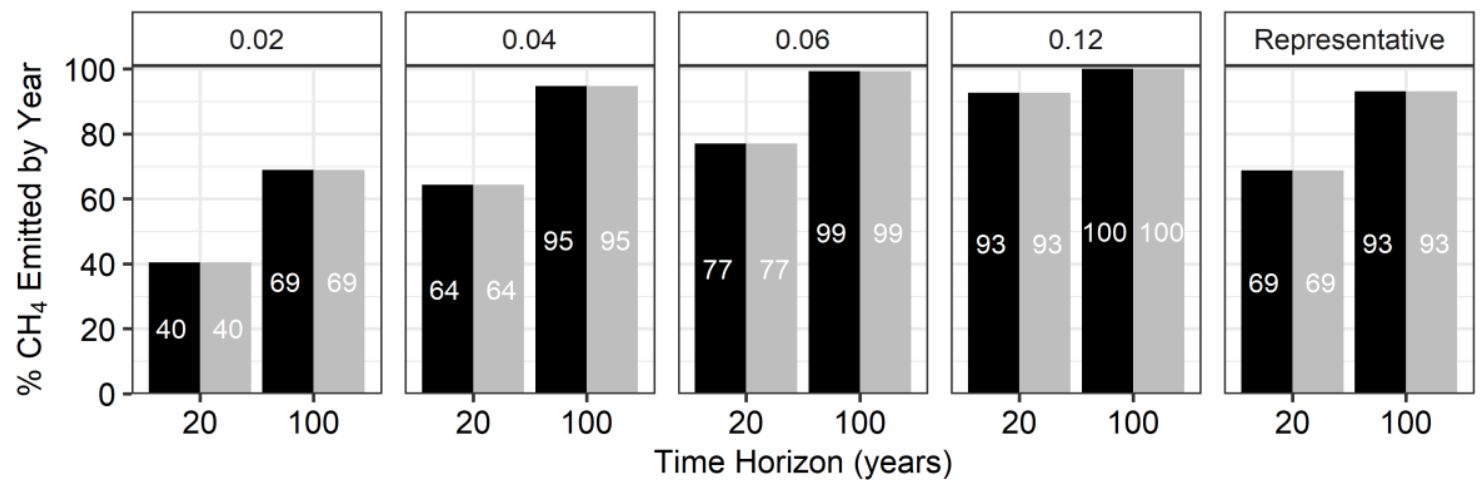

NMOCs (Mg/yr) $\square 34 \square 50$

Figure S25. Percentage of emissions that are released by 20 and 100 yr. Results are based on the energy recovery scenario and EPA Typical collection across five landfill types (i.e., four decay rate constants and the representative landfill that is a weighted average of four decay rates). Results are presented for two NMOCs thresholds and for the mean size and operating life across landfill (233,000 Mg MSW per year and 80 yr operating life).

(a) Flare
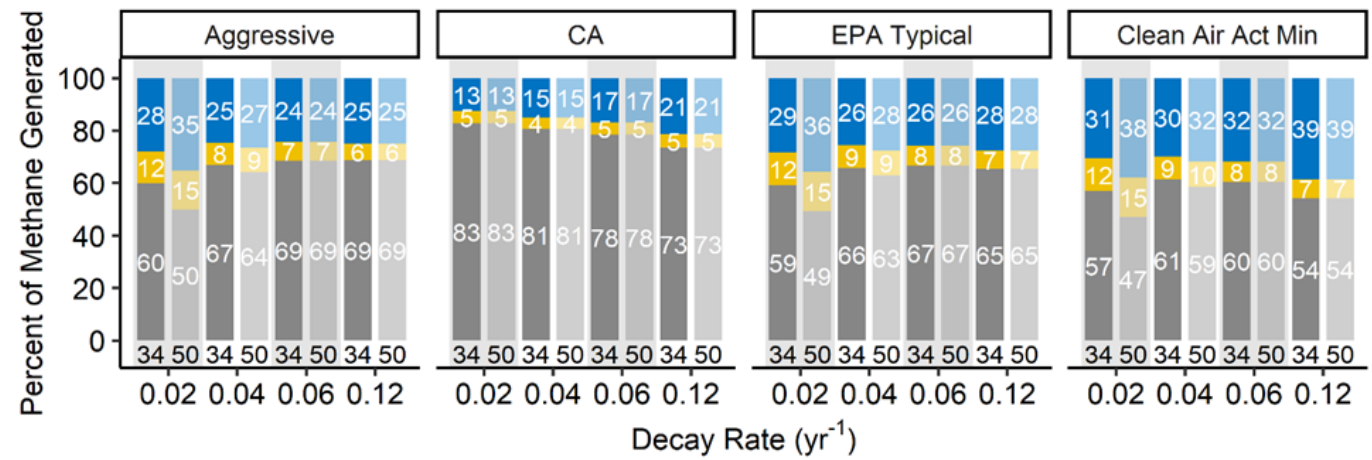

(b) Electricity Recovery
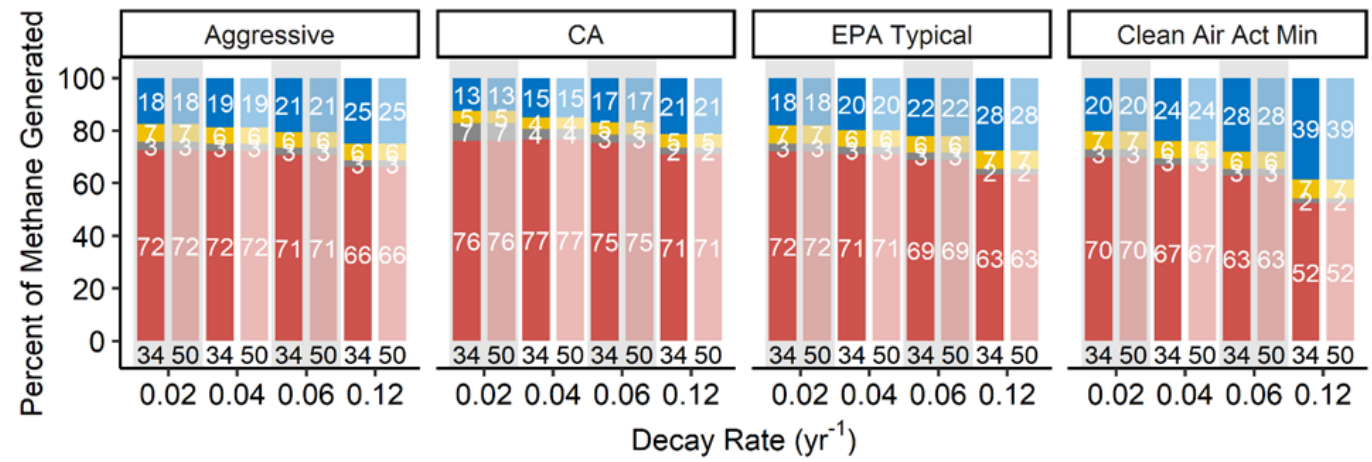

CH4 Emitted

$\mathrm{CH} 4$ Oxidized

$\mathrm{CH} 4$ Flared

$\mathrm{CH} 4$ Combusted for Energy

Figure S26. The fraction of generated methane that is combusted to produce electricity, flared, oxidized, and emitted across two gas treatment and four gas collection scenarios by decay rate, based on the (a) flare and (b) electricity recovery scenarios. The effect of regulatory changes in NMOCs emission thresholds ( $34 \mathrm{vs} 50 \mathrm{Mg} / \mathrm{yr}$ ) is displayed for each case. 


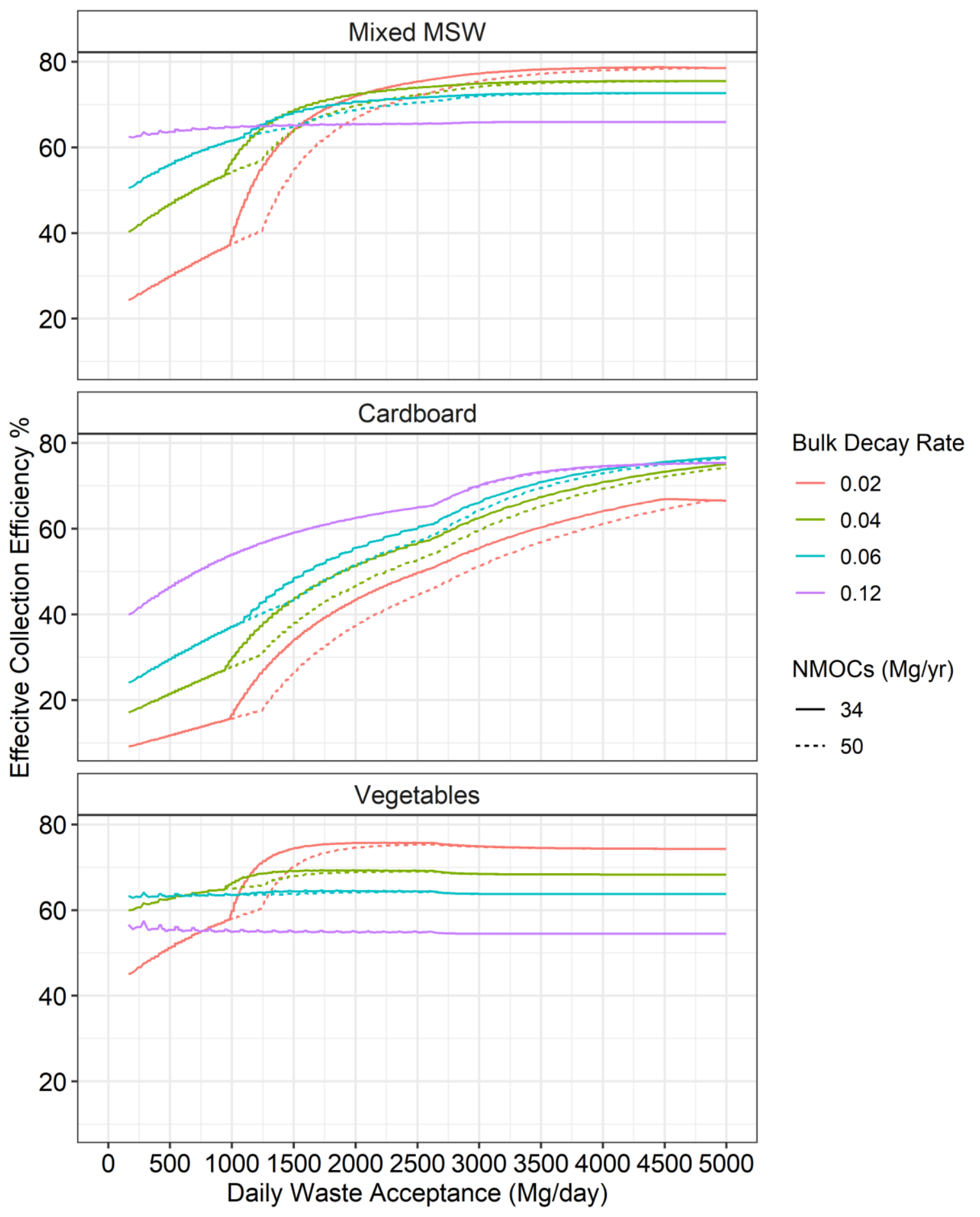

Figure S27. Effective collection efficiency of mixed MSW, corrugated cardboard, and vegetable waste under the flare scenarios with two NMOC thresholds and four decay rates across the range of U.S. landfill sizes. However, the $1^{\text {st }}-3^{\text {rd }}$ quantile range of LMOP landfill database is from 260 to $1020 \mathrm{Mg} /$ day (Table S1). 


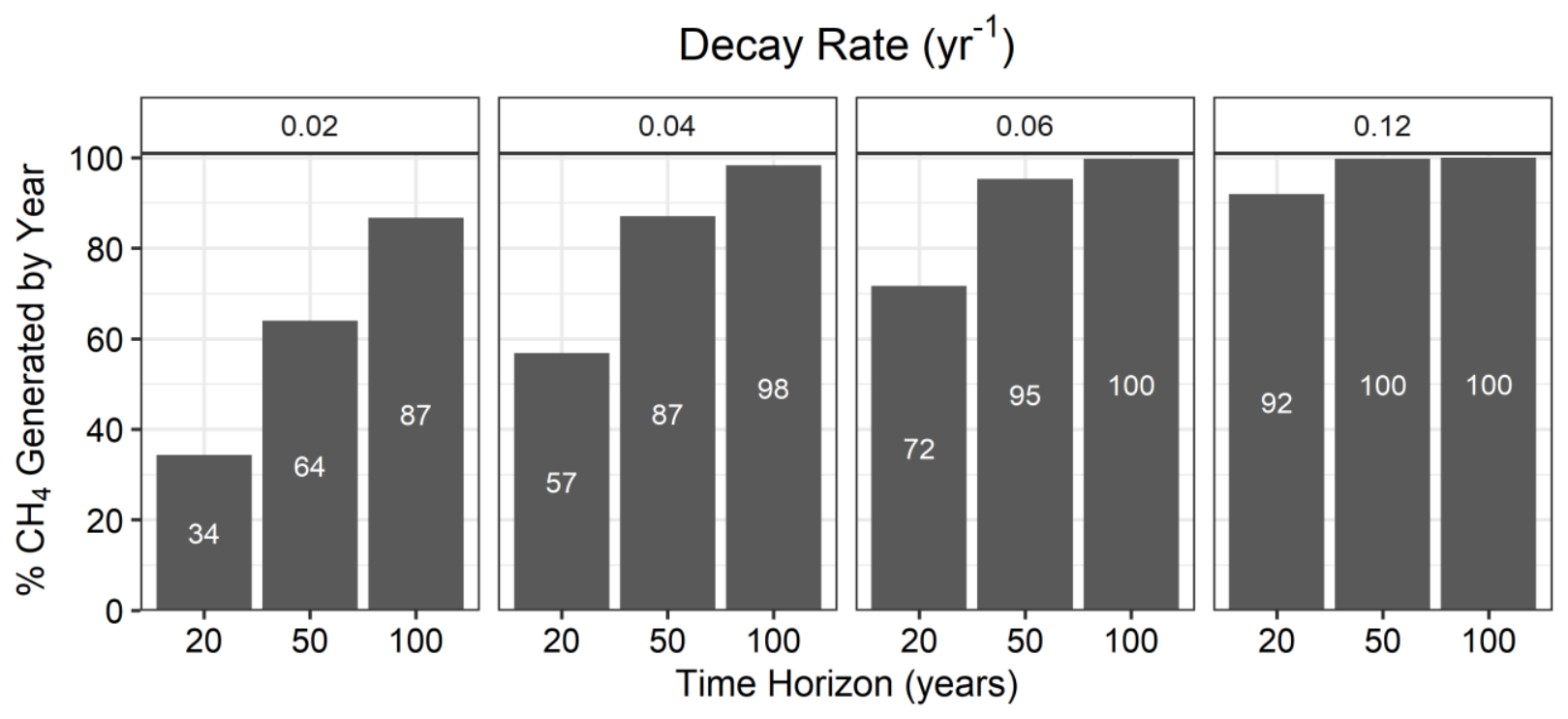

Figure S28. Percentage of $\mathrm{CH}_{4}$ generated by 20, 50, and $100 \mathrm{yr}$ across four decay rate constants 


\section{MONTE CARLO ANALYSIS INPUTS AND DISTRIBUTIONS}

Table S15. Default values, ranges, and distribution of uncertain inputs for Monte Carlo analysis. The given uncertainty range is based on $\pm 10 \%$ of the default value of the parameter, except when we have a better reference from literature or expert judgement as presented in table notes.

\begin{tabular}{|c|c|c|c|c|c|c|c|c|}
\hline $\begin{array}{l}\text { Landfill } \\
\text { Module }\end{array}$ & Parameter & Unit & $\begin{array}{l}\text { Default } \\
\text { Value }\end{array}$ & Distribution & Distribution Hyperparameters & $\boldsymbol{\mu} / \mathrm{min}$ & $\sigma / \max$ & mode \\
\hline Landfill design & Waste acceptance ${ }^{a}$ & $\begin{array}{l}\mathrm{Mg} \\
\mathrm{MSW} / \mathrm{yr}\end{array}$ & 233,091 & Lognormal & $\mu=12.94, \sigma=0.76$ & 12.94 & 0.76 & \\
\hline Landfill design & Height above the grade (mul factor) & unitless & 1 & Uniform & $\min =0.9, \max =1.1$ & 0.9 & 1.1 & \\
\hline Landfill design & Excavation depth (mul factor) & unitless & 1 & Uniform & $\min =0.9, \max =1.1$ & 0.9 & 1.1 & \\
\hline Landfill design & Waste density (small) & $\mathrm{kg} / \mathrm{m}^{3}$ & 890 & Uniform & $\min =711, \max =1008(1200,1700) \mathrm{lb} / \mathrm{yd}^{3}$ & 801 & 979 & \\
\hline Landfill design & Waste density (large) & $\mathrm{kg} / \mathrm{m}^{3}$ & 1068 & Uniform & $\min =1009, \max =1187(1700,2000) \mathrm{lb} / \mathrm{yd}^{3}$ & 961 & 1175 & \\
\hline Capital goods & PCC factor $(\mathrm{a})^{b}$ & unitless & 0 & Uniform & $\min =0, \max =1$ & 0 & 1 & \\
\hline Landfill gas & $\begin{array}{l}\text { Gas collection efficiency (mul } \\
\text { factor) })^{c}\end{array}$ & unitless & 1 & Triangular & $\min =0.9, \max =1.1$, mode $=1$ & 0.9 & 1.1 & 1 \\
\hline Landfill gas & Oxidation efficiency $^{d}$ & $\%$ & 10 & Uniform & $\min =10, \max =55$ & 10 & 55 & \\
\hline Landfill gas & Biogenic carbon content ${ }^{e}$ & $\% \mathrm{MSW}$ & 27 & Triangular & $\min =21, \max =32$ & 21 & 32 & 27 \\
\hline Landfill gas & $\begin{array}{l}\text { Fraction of anaerobically } \\
\text { degradable carbon }^{e}\end{array}$ & $\%$ bio $\mathrm{C}$ & 53 & Triangular & $\min =41, \max =64$ & 42 & 64 & 53 \\
\hline Landfill gas & Bulk decay rate ${ }^{f}$ & $\mathrm{yr}^{-1}$ & 0.04 & Triangular & $\min =0.02, \max =0.17$, mode $=0.04$ & 0.02 & 0.17 & 0.04 \\
\hline Landfill gas & Electricity conversion efficiency ${ }^{g}$ & unitless & 0.35 & Triangular & $\min =0.3, \max =0.4$, mode $=0.35$ & 0.3 & 0.4 & 0.35 \\
\hline Landfill leachate & Initial $\%$ leachate of precipitation & $\%$ & 20 & Uniform & $\min =18, \max =22$ & 18 & 22 & \\
\hline Landfill leachate & Interim $\%$ leachate of precipitation & $\%$ & 13 & Uniform & $\min =11.7, \max =14.3$ & 11.7 & 14.3 & \\
\hline Landfill leachate & Final $\%$ leachate of precipitation & $\%$ & 0.4 & Uniform & $\min =0.7, \max =0.9$ & 0.36 & 0.44 & \\
\hline Landfill leachate & Leachate collection efficiency & $\%$ & 99.1 & Uniform & $\min =97.1, \max =99.9$ & 97.1 & 99.9 & \\
\hline Capital goods & Heavy Equipment Construction & $\mathrm{kg} / \mathrm{Mg}$ & 0.016 & Uniform & $\min =0.014, \max =0.02$ & 0.014 & 0.0176 & \\
\hline Capital goods & Asphalt Construction & $\mathrm{kg} / \mathrm{Mg}$ & 0.085 & Uniform & $\min =0.0765, \max =0.0935$ & 0.077 & 0.0935 & \\
\hline Capital goods & Diesel Construction & $\mathrm{L} / \mathrm{Mg}$ & 0.22 & Uniform & $\min =0.198, \max =0.242$ & 0.198 & 0.242 & \\
\hline Capital goods & Heavy Equipment Closure & $\mathrm{kg} / \mathrm{Mg}$ & 0.062 & Uniform & $\min =0.0558, \max =0.0682$ & 0.056 & 0.0682 & \\
\hline Capital goods & Diesel Closure & $\mathrm{L} / \mathrm{Mg}$ & 0.067 & Uniform & $\min =0.0603, \max =0.0737$ & 0.06 & 0.0737 & \\
\hline Capital goods & Electricity Operation & $\mathrm{kWh} / \mathrm{Mg}$ & 0.081 & Uniform & $\min =0.0729, \max =0.0891$ & 0.073 & 0.0891 & \\
\hline Capital goods & Heavy Equipment Operation & $\mathrm{kg} / \mathrm{Mg}$ & 0.16 & Uniform & $\min =0.144, \max =0.176$ & 0.144 & 0.176 & \\
\hline
\end{tabular}




\begin{tabular}{|c|c|c|c|c|c|c|c|c|}
\hline $\begin{array}{l}\text { Landfill } \\
\text { Module }\end{array}$ & Parameter & Unit & $\begin{array}{l}\text { Default } \\
\text { Value } \\
\end{array}$ & Distribution & Distribution Hyperparameters & $\mu / \min$ & $\sigma / \max$ & mode \\
\hline Capital goods & Diesel Soil extraction & $\mathrm{L} / \mathrm{kg}$ & 1.4 & Uniform & $\min =1.26, \max =1.54$ & 1.26 & 1.54 & \\
\hline Capital goods & Diesel Sand extraction & $\mathrm{L} / \mathrm{kg}$ & 1.8 & Uniform & $\min =1.62, \max =1.98$ & 1.62 & 1.98 & \\
\hline Capital goods & Diesel Aftercare & $\mathrm{L} / \mathrm{Mg}-\mathrm{yr}$ & $2.08 \mathrm{E}-05$ & Uniform & $\min =0.00001872, \max =0.00002288$ & $2 \mathrm{E}-05$ & $\begin{array}{l}0.00002 \\
288\end{array}$ & \\
\hline Capital goods & Thickness of sand in bottom liner & $\mathrm{m}$ & 0.6096 & Triangular & $\min =0.54864, \max =0.67056$, mode $=0.6096$ & 0.549 & 0.67056 & 0.61 \\
\hline Capital goods & Thickness of HDPE in bottom liner & $\mathrm{m}$ & 0.001524 & Triangular & $\begin{array}{l}\min =0.0013716, \max =0.0016764 \\
\text { mode }=0.001524\end{array}$ & 0.001 & $\begin{array}{l}0.00167 \\
64\end{array}$ & 0 \\
\hline Capital goods & Thickness of Clay in bottom liner & $\mathrm{m}$ & 0.6096 & Triangular & $\min =0.54864, \max =0.67056$, mode $=0.6096$ & 0.549 & 0.67056 & 0.61 \\
\hline Capital goods & Thickness of topsoil in top cover & $\mathrm{m}$ & 0.1524 & Triangular & $\min =0.13716, \max =0.16764$, mode $=0.1524$ & 0.137 & 0.16764 & 0.15 \\
\hline Capital goods & Thickness of sand in top cover & $\mathrm{m}$ & 0.3048 & Triangular & $\min =0.27432, \max =0.33528$, mode $=0.3048$ & 0.274 & 0.33528 & 0.3 \\
\hline Capital goods & Thickness of HDPE in top cover & $\mathrm{m}$ & 0.001524 & Triangular & $\begin{array}{l}\min =0.0013716, \max =0.0016764 \\
\text { mode }=0.001524\end{array}$ & 0.001 & $\begin{array}{l}0.00167 \\
64\end{array}$ & 0 \\
\hline Capital goods & Thickness of clay in top cover & $\mathrm{m}$ & 0.6096 & Triangular & $\min =0.54864, \max =0.67056$, mode $=0.6096$ & 0.549 & 0.67056 & 0.61 \\
\hline Capital goods & Clay haul distance Construction & $\mathrm{km}$ & 8 & Uniform & $\min =7.2, \max =8.8$ & 7.2 & 8.8 & \\
\hline Capital goods & Sand haul distance Construction & $\mathrm{km}$ & 32 & Uniform & $\min =28.8, \max =35.2$ & 28.8 & 35.2 & \\
\hline Capital goods & $\begin{array}{l}\text { Heavy Equipment haul distance } \\
\text { Construction }\end{array}$ & $\mathrm{km}$ & 402 & Uniform & $\min =361.8, \max =442.2$ & 361.8 & 442.2 & \\
\hline Capital goods & $\begin{array}{l}\text { Concrete haul distance } \\
\text { Construction }\end{array}$ & $\mathrm{km}$ & 80 & Uniform & $\min =72, \max =88$ & 72 & 88 & \\
\hline Capital goods & Asphalt haul distance Construction & $\mathrm{km}$ & 80 & Uniform & $\min =72, \max =88$ & 72 & 88 & \\
\hline Capital goods & $\begin{array}{l}\text { HDPE (liners and pipes) haul } \\
\text { distance Construction }\end{array}$ & $\mathrm{km}$ & 402 & Uniform & $\min =361.8, \max =442.2$ & 361.8 & 442.2 & \\
\hline Capital goods & $\begin{array}{l}\text { PVC pipes haul distance } \\
\text { Construction }\end{array}$ & $\mathrm{km}$ & 402 & Uniform & $\min =361.8, \max =442.2$ & 361.8 & 442.2 & \\
\hline Capital goods & Fuel haul distance Construction & $\mathrm{km}$ & 80 & Uniform & $\min =72, \max =88$ & 72 & 88 & \\
\hline Capital goods & Clay haul distance Closure & $\mathrm{km}$ & 8 & Uniform & $\min =7.2, \max =8.8$ & 7.2 & 8.8 & \\
\hline Capital goods & Sand haul distance Closure & $\mathrm{km}$ & 32 & Uniform & $\min =28.8, \max =35.2$ & 28.8 & 35.2 & \\
\hline Capital goods & HDPE haul distance Closure & $\mathrm{km}$ & 402 & Uniform & $\min =361.8, \max =442.2$ & 361.8 & 442.2 & \\
\hline Capital goods & PVC haul distance Closure & $\mathrm{km}$ & 402 & Uniform & $\min =361.8, \max =442.2$ & 361.8 & 442.2 & \\
\hline Capital goods & Fuel haul distance Closure & $\mathrm{km}$ & 80 & Uniform & $\min =72, \max =88$ & 72 & 88 & \\
\hline Capital goods & Heavy Equipment haul distance & $\mathrm{km}$ & 80 & Uniform & $\min =72, \max =88$ & 72 & 88 & \\
\hline Capital goods & Fuel haul distance & $\mathrm{km}$ & 402 & Uniform & $\min =361.8, \max =442.2$ & 361.8 & 442.2 & \\
\hline
\end{tabular}




\begin{tabular}{|c|c|c|c|c|c|c|c|c|}
\hline $\begin{array}{l}\text { Landfill } \\
\text { Module }\end{array}$ & Parameter & Unit & $\begin{array}{l}\text { Default } \\
\text { Value } \\
\end{array}$ & Distribution & Distribution Hyperparameters & $\boldsymbol{\mu} / \mathrm{min}$ & $\sigma / \max$ & mode \\
\hline Capital goods & Medium truck payload & $\begin{array}{l}\mathrm{Mg} / \\
\text { vehicle }\end{array}$ & 24 & Uniform & $\min =21.6, \max =26.4$ & 21.6 & 26.4 & \\
\hline Capital goods & Heavy truck payload & $\begin{array}{l}\mathrm{Mg} / \mathrm{vehi} \\
\text { cle }\end{array}$ & 35 & Uniform & $\min =31.5, \max =38.5$ & 31.5 & 38.5 & \\
\hline
\end{tabular}

${ }^{a}$ The values were based on the LMOP landfill database and the developed lognormal distribution in Table 1.

${ }^{b}$ This post-closure care (PCC) factor corresponds to a cover replacement of 10 to $100 \%$ over 30 to $100 \mathrm{yr}$ PCC. Considering more cover replaced over a longer PCC period, PCC factor $a$ was used to indicate the correlation between the \% cover replacement and PCC period: (1) \% cover replacement: $10 \%+\mathrm{a} *(100 \%-10 \%)$ and (2) PCC period: 30 yr + a * $(100 \mathrm{yr}-30 \mathrm{yr})$, where a defines the correlated (same) increasing rate from the minimum assumption for either parameter. Then, by varying a between 0 and 1 , we can do the sensitivity analysis on both parameters that are correlated. For example, the default case is a $=0$ where we replace $10 \%$ of the cover over 30 -yr PCC; if a $=0.5$, we replace $55 \%$ over 65 years.

${ }^{c}$ Judgment based on the values for the better and worse collection case relative to the typical one presented in Table S11.

${ }^{d}$ The minimum oxidation rate of $10 \%$ is recommended by the EPA's AP-42 database ${ }^{14}$ and the judgment for the maximum value (55\%) is based on Chanton et al., $2009 .{ }^{15}$

${ }^{e}$ Biogenic carbon content and fraction of biogenic carbon converted to biogas were varied to represent the uncertainty in waste composition. These ranges correspond to a range of $\mathrm{L}_{0}$ between $64-144 \mathrm{~m}^{3} / \mathrm{Mg}$ wet MSW with a default value of $100 \mathrm{~m}^{3} / \mathrm{Mg}$, and the judgement is adjusted based on Sun et al. (2019) $)^{16}$ and Staley et al. (2009). ${ }^{17}$ There is

considerable uncertainty in the value of $\mathrm{L}_{0}$ but a lot of waste composition data is old and not useful to quantify variations by region. Seasonal and socioeconomic factors are likely more important.

${ }^{f}$ Adopted from IPCC (2006). ${ }^{18}$

${ }^{8}$ The internal combustion engine (ICE) is most commonly used in energy recovery of LFGs because of low cost and high electricity efficiency. $30 \%$ to $40 \%$ conversion efficiencies can be achieved by the ICE based on the LFG energy projects 2017 in the US. ${ }^{19}$ 


\section{EFFECT OF NMOC THRESHOLD ON GAS COLLECTION EFFICIENCY UNDER UNCERTAINTY}

The stricter NMOC threshold generally increases the effective collection efficiency by $<5 \%$ points on average across all iterations under uncertainty (Figure S29). However, uncertainty in the improved averaged collection efficiency increases with decreasing decay rate. A decay rate of 0.02 $\mathrm{yr}^{-1}$ is more sensitive to the stricter NMOC threshold than landfills with higher decay rates. This is because $\sim 30 \%$ of emissions are released after collection and control ceases when the decay rate is $0.02 \mathrm{yr}^{-1}$.

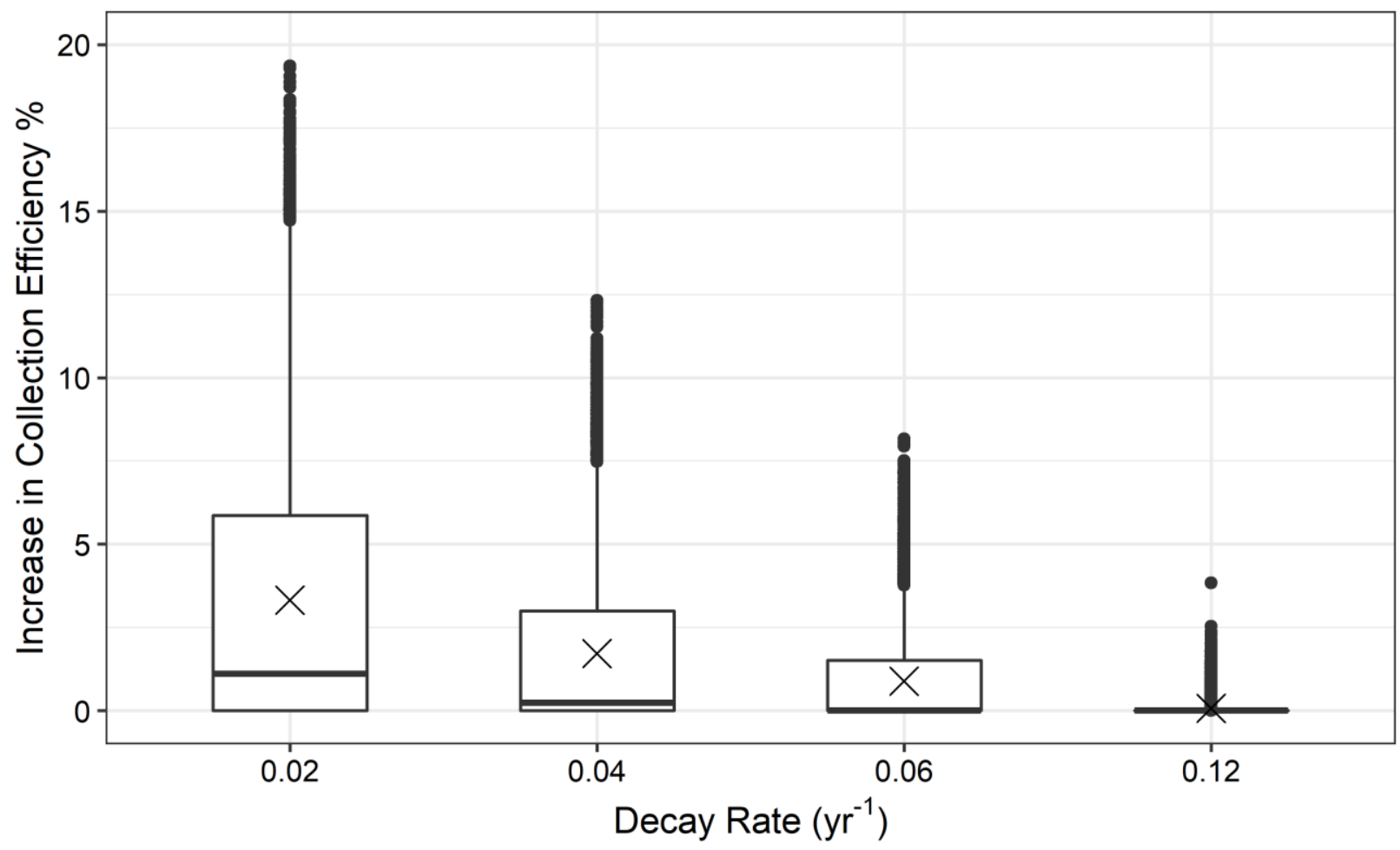

Figure S29. Boxplot showing the uncertainties associated with the increase in collection efficiency due to lowering the NMOC threshold from 50 to $34 \mathrm{Mg} / \mathrm{yr}$ across four decay rates. The outcome uncertainty is based on a 5,000-iteration Monte Carlo analysis considering the uncertain ranges and distributions of all the inputs summarized in Table S15. The $\times$ represents the mean of each data set, while the interior line represents the median. The boxes bound the interquartile range (IQR) (25th to 75th quartile). The whiskers extend to 1.5 times the IQR, and their ends show the highest and lowest value excluding outliers, which are represented by solid black points. 


\section{REFERENCE}

(1) USEPA. Landfill Methane Outreach Program (LMOP): Landfill Technical Data https://www.epa.gov/lmop/landfill-technical-data (accessed Jun 15, 2020).

(2) US EPA. GHG Reporting Program Data Sets | Greenhouse Gas Reporting Program https://www.epa.gov/ghgreporting/ghg-reporting-program-data-sets (accessed Mar 16, 2021).

(3) ecoinvent https://www.ecoinvent.org/home.html (accessed Sep 25, 2020).

(4) Inc., E. Life Cycle Inventory of a Modern Municipal Solid Waste Landfill; Washington, DC.

(5) Ecobalance Inc. Life Cycle Inventory of a Modern Municipal Solid Waste Landfill; Washington DC, 1999.

(6) Alexander, A.; Burklin, C.; Singleton, A. Landfill Gas Emissions Model (LandGEM) Version 3.02 User's Guide; 2005.

(7) Levis, J. W.; Barlaz, M. A. Landfill Gas Monte Carlo Model Documentation and Results. Report to ICF for the U.S. EPA Waste Reduction Model (WARM); Washington, DC, 2014.

(8) Levis, J. W.; Barlaz, M. A. Life-Cycle Modeling of Municipal Solid Waste Landfills. In Geotechnical Special Publication; American Society of Civil Engineers (ASCE), 2017; pp 355-359. https://doi.org/10.1061/9780784480434.038.

(9) Cruz, F. B. D. La; Barlaz, M. A. Estimation of Waste Component-Specific Landfill Decay Rates Using Laboratory-Scale Decomposition Data; American Chemical Society, 2010; Vol. 44. https://doi.org/10.1021/es100240r.

(10) North Carolina State University; Eastern Research Group. Final Background Information Document for Life-Cycle Inventory Landfill Process Model; 2011.

(11) Bonaparte, R.; David, P. E.; Daniel, E.; Robert, P. E.; Koerner, M.; Geosyntec Consultants, P. E.; David, M.; Carson, A. Assessment and Recommendations for Improving the Performance of Waste Containment Systems Active Period of Operation Post-Closure Initial Period of Operation MSW Landfill (Pennsylvania) Period by Performed under EPA Cooperative Agreement Number; 2002.

(12) Ryberg, M.; Vieira, M. D. M.; Zgola, M.; Bare, J.; Rosenbaum, R. K. Updated US and Canadian Normalization Factors for TRACI 2.1. Clean Technol. Environ. Policy 2014, 16 (2), 329-339. https://doi.org/10.1007/s10098-013-0629-z.

(13) US EPA. AP 42, Fifth Edition, Volume I - Chapter 2 Solid Waste Disposal (2-4 Municipal Solid Waste Landfills); 2008.

(14) USEPA. Chapter 2: Solid Waste Disposal, AP 42, Fifth Edition, Volume I.

(15) Chanton, J. P.; Powelson, D. K.; Green, R. B. Methane Oxidation in Landfill Cover Soils, Is a 10\% Default Value Reasonable? J. Environ. Qual. 2009, 38 (2), 654. https://doi.org/10.2134/jeq2008.0221.

(16) Sun, W.; Wang, X.; DeCarolis, J. F.; Barlaz, M. A. Evaluation of Optimal Model Parameters for Prediction of Methane Generation from Selected U.S. Landfills. Waste Manag. 2019, 91, 120-127. https://doi.org/10.1016/j.wasman.2019.05.004.

(17) Staley, B. F.; Barlaz, M. A. Composition of Municipal Solid Waste in the United States and Implications for Carbon Sequestration and Methane Yield. J. Environ. Eng. 2009, 135 (10), 901-909. https://doi.org/10.1061/(asce)ee.1943-7870.0000032.

(18) Intergovernmental Panel on Climate Change (IPCC). IPCC - Task Force on National Greenhouse Gas Inventories; Paris, France, 2006; Vol. 2. 
(19) USEPA. Landfill Methane Outreach Program Chapter 3: Project Technology Options; 2017. 